\title{
Quality of Surface Water and Ground Water in the Proposed Artificial- Recharge Project Area, Rillito Creek Basin, Tucson, Arizona, 1994 By SAEID TADAYON
}

U.S. GEOLOGICAL SURVEY

Water-Resources Investigations Report 95-4270

Prepared in cooperation with the PIMA COUNTY DEPARTMENT OF TRANSPORTATION AND FLOOD CONTROL DISTRICT

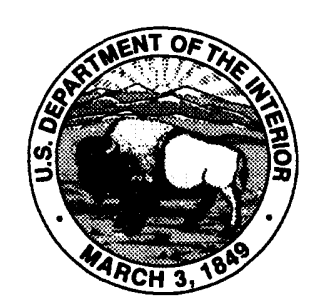




\section{U.S. DEPARTMENT OF THE INTERIOR \\ BRUCE BABBITT, Secretary}

U.S. GEOLOGICAL SURVEY

Gordon P. Eaton, Director

Any use of trade, product, or firm names in this publication is for descriptive purposes only and does not constitute endorsement by the U.S. Government.

For additional information write to:

District Chief U.S. Geological Survey Water Resources Division 375 South Euclid Avenue Tucson, AZ 85719-6644
Copies of this report can be purchased from:

U.S. Geological Survey Open-File Section Box 25286, MS 517 Denver Federal Center Denver, CO 80225 


\section{CONTENTS}

Abstract
Introduction
Purpose and scope tons
Previous investigations
Description of the study area
Sample collection and analysis
Quality of surface water
Quality of ground water
Selected references.
Basic data

\section{FIGURES}

1. Map showing location of study area and surface-water and ground-water data-collection sites, Rillito Creek basin, Arizona

2. Map showing location of Rillito Creek basin in the Tucson basin..

3. Hydrograph of flow in Tanque Verde Creek and water levels in monitoring wells (D-13-14)26cbb2 and (D-13-14)26dcb2, 1994

4. Trilinear diagram showing compositions of surface water and ground water in the proposed artificial-recharge project area, Rillito Creek basin, Tucson, Arizona, 1994

\section{TABLES}

1. Water-quality standards for selected constituents

2. Suspended-sediment concentration and particle-size distribution in surface-water samples, Rillito Creek basin.

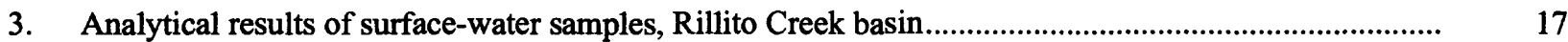

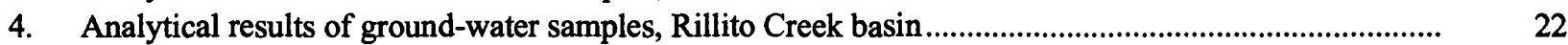

\section{CONVERSION FACTORS}

\begin{tabular}{lcl}
\hline Multiply & By & To obtaln \\
\hline meter $(\mathrm{m})$ & 3.281 & foot \\
square meter $\left(\mathrm{m}^{2}\right)$ & 10.76 & square foot \\
kilometer $(\mathrm{km})$ & 0.6214 & mile \\
cubic meter per second $\left(\mathrm{m}^{3} / \mathrm{s}\right)$ & 35.31 & cubic foot per second \\
\hline
\end{tabular}

In this report, temperature is reported in degrees Celsius $\left({ }^{\circ} \mathrm{C}\right)$, which can be converted to degrees Fahrenheit $\left({ }^{\circ} \mathrm{F}\right)$ by the following equation:

$$
{ }^{\circ} \mathrm{F}=1.8\left({ }^{\circ} \mathrm{C}\right)+32
$$




\section{ABBREVIATED UNITS FOR WATER QUALITY}

Chemical concentration and water temperature are given only in metric units. Chemical concentration in water is given in milligrams per liter $(\mathrm{mg} / \mathrm{L})$ or micrograms per liter $(\mu \mathrm{g} / \mathrm{L})$. Milligrams per liter is a unit expressing the solute mass per unit volume (liter) of water. One thousand micrograms per liter is equivalent to 1 milligram per liter. For concentrations less than 7,000 milligrams per liter, the numerical value is about the same as for concentrations in parts per million. Specific conductance is given in microsiemens per centimeter $(\mu \mathrm{S} / \mathrm{cm})$ at $25^{\circ} \mathrm{C}$. Fecal coliform and fecal streptococcal bacteria are reported in colonies per 100 milliliter $(\mathrm{col} / 100 \mathrm{~mL})$.

\section{WELL-NUMBERING SYSTEM}
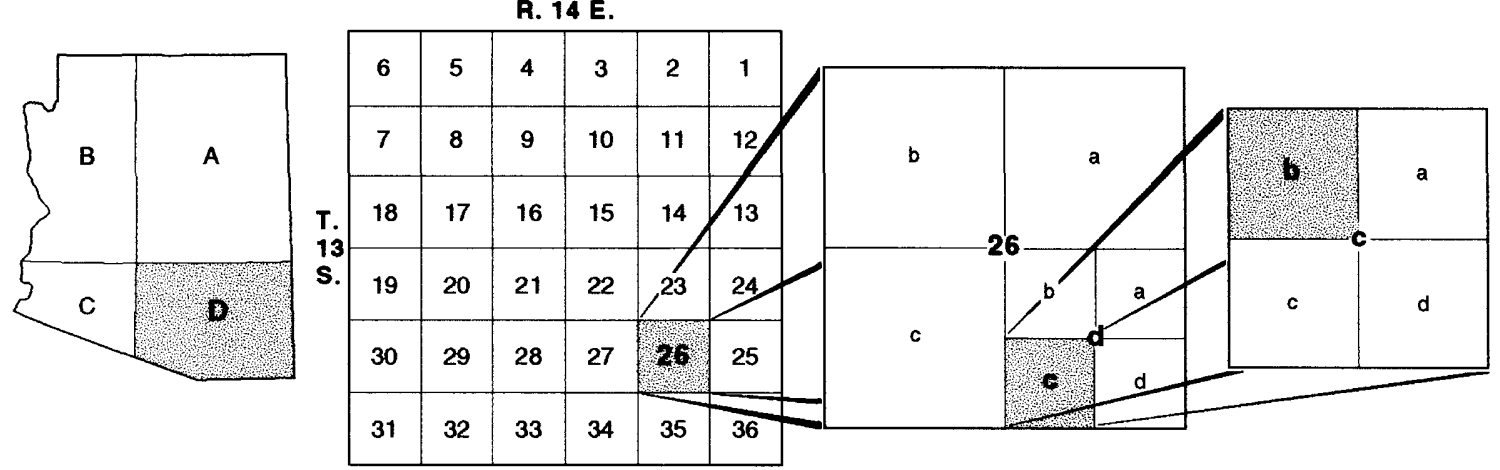

\section{Quadrant D, Township 13 South, Range 14 East, section 26, quarter section d, quarter section c, quarter section b, second well inventoried in 10-acre tract}

The well numbers used by the U.S. Geological Survey in Arizona are in accordance with the Bureau of Land Management's system of land subdivision. The land survey in Arizona is based on the Gila and Salt River meridian and base line, which divide the State into four quadrants and are designated by capital letters A, B, C, and D in a counterclockwise direction beginning in the northeast quarter. The first digit of a well number indicates the township, the second the range, and the third the section in which the well is situated. The lowercase letters $\mathrm{a}, \mathrm{b}, \mathrm{c}$, and $\mathrm{d}$ after the section number indicate the well location within the section. The first letter denotes a particular 160 -acre tract, the second the 40 -acre tract and the third the 10 -acre tract. These letters also are assigned in a counterclockwise direction beginning in the northeast quarter. If the location is known within the 10 -acre tract, three lowercase letters are shown in the well number. Where more than one well is within a 10-acre tract, consecutive numbers beginning with 1 are added as suffixes. In the example shown, well number (D-13-14)26dcb2 designates the well as being in the NW1/4, SW1/4, SE1/4, section 26, Township 13 South, and Range 14 East.

\section{VERTICAL DATUM}

Sea Level: In this report, "sea level" refers to the National Geodetic Vertical Datum of $1929-$ a geodetic datum derived from a general adjustment of the first-order level nets of the United States and Canada, formerly called Sea Level Datum of 1929. 


\title{
Quality of Surface Water and Ground Water in the Proposed Artificial-Recharge Project Area, Rillito Creek Basin, Tucson, Arizona, 1994
}

\author{
By Saeid Tadayon
}

\begin{abstract}
Controlled artificial recharge of surface runoff is being considered as a water-management technique to address the problem of ground-water overdraft. The planned use of recharge facilities in urban areas has caused concern about the quality of urban runoff to be recharged and the potential for ground-water contamination. The proposed recharge facility in Rillito Creek will utilize runoff entering a 1-mile reach of the Rillito Creek between Craycroft Road and Swan Road for infiltration and recharge purposes within the channel and excavated overbank areas.

Physical and chemical data were collected from two surface-water and two ground-water sites in the study area in 1994. Analyses of surface-water samples were done to determine the occurrence and concentration of potential contaminants and to determine changes in quality since samples were collected during 1987-93. Analyses of ground-water samples were done to determine the variability of ground-water quality at the monitoring wells throughout the year and to determine changes in quality since samples were collected in 1989 and 1993. Surface-water samples were collected from Tanque Verde Creek at Sabino Canyon Road (streamflow-gaging station Tanque Verde Creek at Tucson, 09484500) and from Alamo Wash at Fort Lowell Road in September and May 1994, respectively. Ground-water samples were collected from monitoring wells (D-13-14)26cbb2 and (D-13-14)26dcb2 in January, May, July, and October 1994.

In surface water, calcium was the dominant cation, and bicarbonate was the dominant anion. In ground water, calcium and sodium were the dominant cations and bicarbonate was the dominant anion. Surface water in the area is soft, and ground water is moderately hard to hard. In surface water and ground water, nitrogen was found predominantly as nitrate. Concentrations of manganese in ground-water samples ranged from 60 to 230 micrograms per liter and exceeded the U.S. Environmental Protection Agency secondary maximum contaminant level for drinking water of 50 micrograms per liter. None of the constituents in surface-water and ground-water samples exceeded the U.S. Environmental Protection Agency primary maximum contaminant levels for drinking water or State of Arizona aquifer water-quality standards. Concentrations of major ions, nutrients, and trace elements in water from the monitoring wells did not vary significantly throughout the year and were not significantly different from concentrations in samples collected in March 1989 and January and September 1993.

Priority pollutants were not found in surface-water samples or ground-water samples, and organochlorine pesticides were not found in ground-water samples. Dieldrin and biphenyl polychlor were the only pesticides found in surface water and were at the minimum reporting levels in one sample from Alamo Wash.
\end{abstract}




\section{INTRODUCTION}

Controlled artificial recharge of surface runoff is being considered as a water-management technique to address the problem of ground-water overdraft. The Pima County Department of Transportation and Flood Control District (PCFCD) suggested a site on Rillito Creek in Tucson, Arizona, in order to utilize snowmelt and stormwater runoff for artificial recharge. The PCFCD in cooperation with the Bureau of Reclamation developed plans for the implementation of a ground-water recharge project within a 1-mile reach of Rillito Creek between Craycroft and Swan Roads in north-central Tucson (fig. 1). The proposed Rillito Creek ground-water recharge project would utilize snowmelt and storm runoff for infiltration and recharge purposes within the channel and excavated overbank areas. This proposed recharge would be accomplished by water spreading and detention using an inflatable dam. Urban runoff in Alamo Wash would be recharged to an off-channel basin (CH2M Hill, 1992).

The planned use of recharge facilities in urban areas has caused concern about the quality of runoff to be recharged and the potential for ground-water contamination. Runoff from developed areas is exposed to a broad range of contaminant sources, and the presence of particular contaminants may depend on the type of land use. Prior to 1986, little was known about the chemical quality of runoff from a southwestern urbanized environment, and even less was known about the potential for contamination of ground water by recharge of urban runoff in the Tucson area.

As part of the ground-water recharge study in Rillito Creek, a monitoring plan was developed to collect physical and chemical data for surface water, ground water, and bottom sediment in the Rillito Creek basin from August 1986 through February 1992. During this phase of monitoring, 18 of the 35 samples from four surface-water sites were collected when discharge was greater than $300 \mathrm{ft}^{3} / \mathrm{s}$. As part of this monitoring, ground water in the study area was sampled from 14 wells during dry periods during 1986-89 (Tadayon and Smith, 1994). In December 1992, the U.S. Geological Survey (USGS) in cooperation with PCFCD collected additional data for surface water, ground water, and bottom sediment. Because the project is designed to impound low-flow stormwater for infiltration and recharge purposes, 13 of 16 samples were collected at discharges of less than $300 \mathrm{ft}^{3} / \mathrm{s}$ from December 1992 through August 1993. Ground water was sampled from six monitoring wells in January and September 1993 and analyzed to determine if the natural recharge from surface water in December 1992 and January and August 1993 had an immediate effect on ground-water quality (Tadayon, 1995).

In January 1994, the USGS, in cooperation with the PCFCD, began collecting additional surface-water and ground-water data. As of 1995, only natural recharge is occurring in the Rillito Creek, and the artificial-recharge facility has not been built. Samples were collected from Tanque Verde Creek at Sabino Canyon Road (streamflow-gaging station Tanque Verde Creek at Tucson, 09484500) and from Alamo Wash at Fort Lowell Road and were analyzed to determine the occurrence and concentrations of potential contaminants in surface water and to determine changes in quality since samples were collected during 1987-93. Samples were collected from two monitoring wells in January, May, July, and October 1994 and were analyzed to determine the variability of ground-water quality throughout the year and to determine changes in quality since samples were collected in 1989 and 1993.

\section{Purpose and Scope}

The purpose of this report is to present the results of physical and chemical data from surfacewater and ground-water sites in the study area, to provide comparisons of the surface-water and ground-water data with water-quality standards, and to provide comparisons of surface-water and ground-water data collected in 1994 with data collected during 1987-93 (Tadayon and Smith, 1994; Tadayon. 1995). This report includes physical and chemical data from two surface-water and two ground-water sites in the study area during January-October 1994. Surface-water samples were collected from Tanque Verde Creek at Sabino Canyon Road (streamflow-gaging station Tanque Verde Creek at Tucson, 09484500) in September 


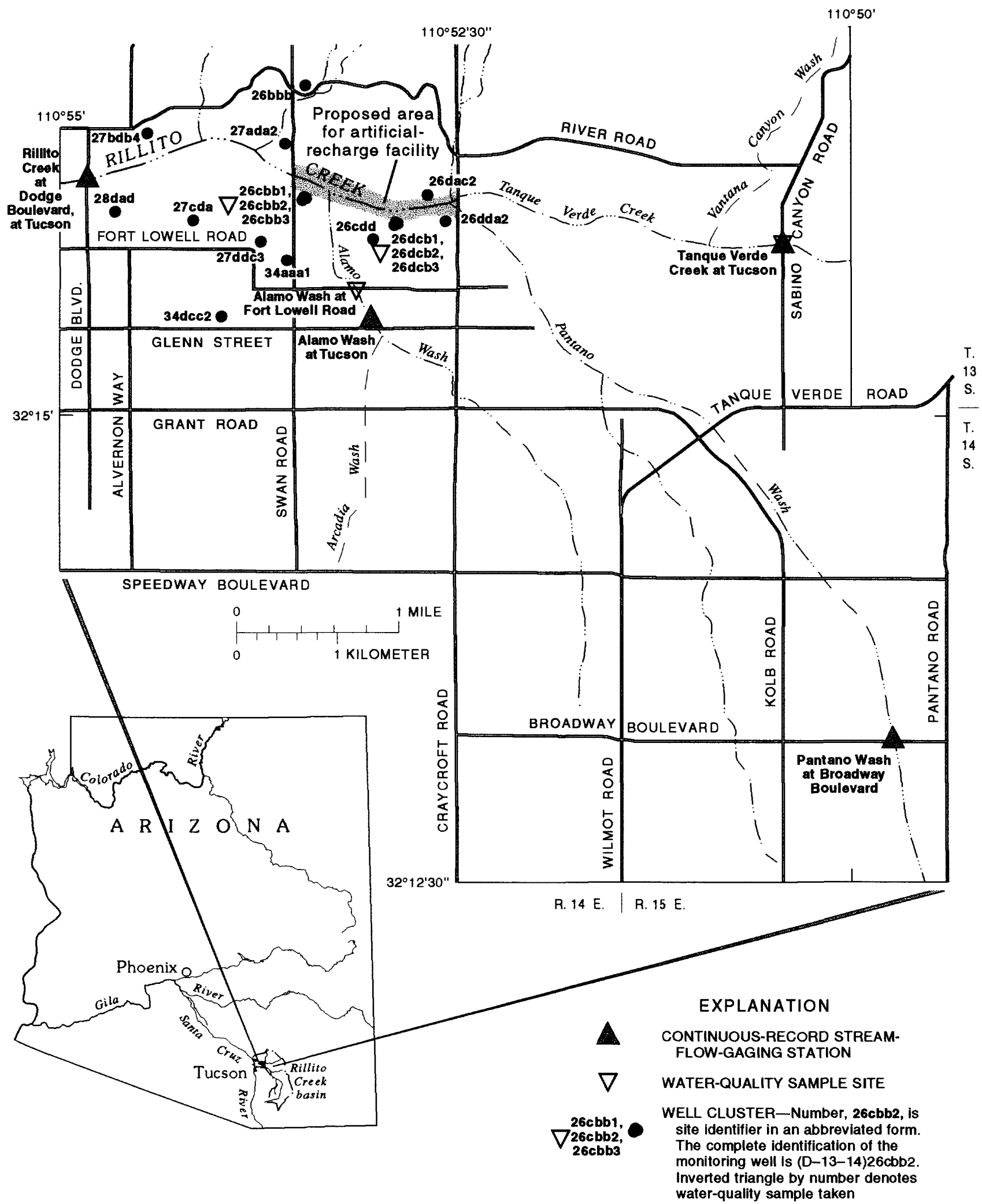

Figure 1. Location of study area and surface-water and ground-water data-collection sites, Rillito Creek basin, Arizona. 
and from Alamo Wash at Fort Lowell Road in May. Samples were collected from monitoring wells (D-13-14)26cbb2 and (D-13-14)26dcb2 in January, May, July, and October.

\section{Previous Investigations}

Two reports have been prepared by the USGS on the monitoring phase of the program (Tadayon and Smith, 1994; Tadayon, 1995). These reports contain data on physical characteristics and chemistry of surface-water, ground-water, and bottom-sediment sites in the Rillito Creek basin during 1986-93. CH2M Hill (1988a, b) reported on the quality of water sources for artificial recharge and the quality of ground water in the Tucson basin. CH2M Hill (1992) then designed two alternatives for a multipurpose artificial-recharge facility along Rillito Creek between Swan Road and Craycroft Road. Camp Dresser \& McKee, Inc. (1990) reported on the availability of water sources for recharge including floodwaters, reclaimed water, and water from the Central Arizona Project aqueduct. Camp Dresser \& McKee, Inc. also assessed the quality of the water sources that might be recharged at the site and the potential effects on existing ground water. Barnes (1988) published ground-water quality data from August 1986 through June 1987 for 11 of the monitoring wells shown in figure 1.

\section{Description of the Study Area}

The proposed location of the artificial-recharge facility is within a 1-mile reach of Rillito Creek between Craycroft Road and Swan Road in north-central Tucson (fig. 1). The Rillito Creek basin encompasses about $918 \mathrm{mi}^{2}$ in the Tucson basin (Garrett and Gellenbeck, 1991). The main tributaries to Rillito Creek are Tanque Verde Creek, Pantano Wash, and Alamo Wash. Rillito Creek flows about $12 \mathrm{mi}$ west-northwestward from the confluence of Pantano Wash and Tanque Verde Creek to the Santa Cruz River (fig. 2). Rillito Creek at Dodge Boulevard (fig. 1) drains $871 \mathrm{mi}^{2}$ of mountain and desert areas, and about $34 \mathrm{mi}^{2}$ of urban area. Tanque Verde Creek at Sabino Canyon Road drains $219 \mathrm{mi}^{2}$ of mainly rural area, including mountainous areas in the northeastern part of the basin, and is dominated by winter flows. Pantano Wash at Broadway Boulevard drains $599 \mathrm{mi}^{2}$ of the southern and southeastern parts of the basin and is dominated by summer flows. Alamo Wash at Glenn Street (streamflow-gaging station, Alamo Wash at Tucson, 09485570) drains $9.58 \mathrm{mi}^{2}$ of urban area. Rillito Creek and its tributaries are ephemeral, which means that flow in the stream generally is in response to precipitation (Condes de la Torre, 1970).

Streamflow in Rillito Creek and its tributaries varies in response to seasonal storm type. Summer flows generally result suddenly from intense, localized thunderstorms and have high peak discharges, short duration, and large suspendedsediment concentrations. Winter flows, which generally result from more widespread frontal storms, have lower peak discharges, longer duration, and smaller suspended-sediment concentrations (Matlock, 1965). Streamflow originating in the Tanque Verde Creek watershed is from rainfall and snowmelt. Flow in Rillito Creek, Pantano Wash, and Alamo Wash generally is from rainfall runoff. Runoff from local rainfall may last for several hours; however, streamflow from snowmelt may last for several weeks or more. The average annual discharge passing the streamflow-gaging station, Rillito Creek near Tucson, was 11,660 acre-ft for 67 years of record for 1908-75 (U.S. Geological Survey, 1976).

The Rillito Creek basin is within the Tucson basin, which is underlain by several thousand feet of unconsolidated and semiconsolidated alluvial material (Burkham, 1970). The alluvial units of the Tucson basin are the Pantano Formation of Oligocene age, the Tinaja beds of Miocene and Pliocene age, the Fort Lowell Formation of Pleistocene age, and the surficial deposits of Pleistocene and Holocene age. The unconfined aquifer that underlies the Tucson basin consists of these sedimentary units that are hydraulically interconnected. The Tucson aquifer is more than $2,000 \mathrm{ft}$ thick and is composed mainly of loosely consolidated to moderately cemented silty sand to silty gravel. The Fort Lowell Formation is the most productive part of the aquifer and is 300 to $400 \mathrm{ft}$ thick in most of the basin and thins toward the mountains (Davidson, 1973). 


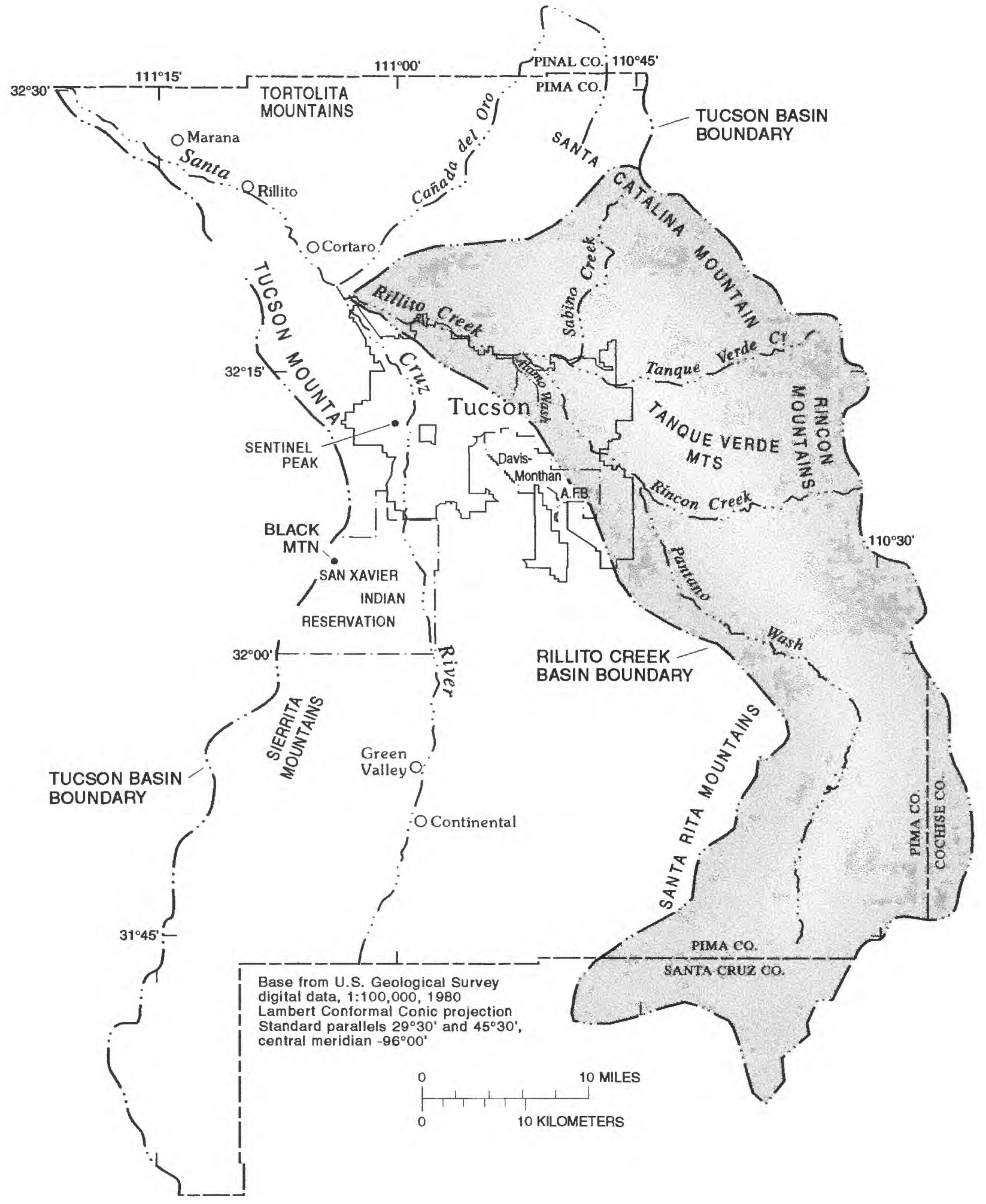

Figure 2. Location of Rillito Creek basin in the Tucson basin. 
According to Davidson (1973), recharge of the Tucson aquifer occurs primarily from infiltration of runoff and averages 51,000 acre-ft/yr; mountainfront recharge averages 31,000 acre- $\mathrm{ft} / \mathrm{yr}$; and subsurface inflow averages $17,000 \mathrm{acre}-\mathrm{ft} / \mathrm{yr}$. Other sources of recharge include return flows from water pumped for irrigation, public supply, and industrial use. Water levels in the monitoring wells ranged from 2,373 to $2,360 \mathrm{ft}$ above sea level at well (D-13-14)26cbb2 and from 2,377 to $2,359 \mathrm{ft}$ above sea level at well (D-13-14)26dcb2 at the time of sampling in 1994 (fig. 3; table 4 in the "Basic Data" section at the end of report).

The climate of southeastern Arizona is semiarid and is characterized by hot summers and mild winters. The area has two distinct rainfall seasons, and about 50 percent of the annual precipitation occurs during the summer season. Summer rainfall is characterized by localized high-intensity and short-duration storms. Winter rainfall generally is less intense and of longer duration. Precipitation at the University of Arizona in Tucson was 14.56 in. in 1994, and the air temperature ranged from a monthly mean of $12.81^{\circ} \mathrm{C}\left(55.05^{\circ} \mathrm{F}\right)$ in January to $34.10^{\circ} \mathrm{C}\left(93.35^{\circ} \mathrm{F}\right)$ in July (U.S. Department of Commerce, 1994).

\section{SAMPLE COLLECTION AND ANALYSIS}

Surface-water samples were collected from Tanque Verde Creek and from Alamo Wash in September and May 1994, respectively (fig. 1). Samples were collected using equal-widthincrement methods and composited according to procedures described by the USGS (1977). Samples were analyzed for suspended-sediment concentration; particle-size distribution; properties; and concentrations of major ions, nutrients, organic carbon, trace elements, organochlorine pesticides, and priority pollutants.

Ground-water samples were collected from monitoring wells (D-13-14)26cbb2 and (D-13-14)26dcb2 in January, May, July, and October 1994. Before samples were collected, each monitoring well was purged using a portable submersible pump until a volume of water that equaled three casing volumes was removed. Specific conductance, $\mathrm{pH}$, and temperature were continually monitored during the purging process using a flow-through chamber, and samples were collected after measurements stabilized. Samples were collected using a stainless-steel bailer and were analyzed for properties, major ions, nutrients, organic carbon, bacteria, trace elements, organochlorine pesticides, and priority pollutants.

Water samples collected for determination of dissolved inorganic constituents were filtered through 0.45-micrometer membrane filters using a peristaltic pump. A special stainless-steel filter unit consisting of 0.45 -micrometer silver-membrane filters, a small pressure cylinder of nitrogen gas, and a pressure regulator were used for filtering samples to be analyzed for dissolved organic carbon content. Water samples collected for analyses of total constituents were not filtered. Samples were treated and preserved according to recommended methods of the USGS (1985). Nitric acid was added to water samples for the determination of most major ions and trace elements; potassium dichromate was added to samples collected for mercury analysis; and mercuric chloride was added to samples collected for nutrient analysis.

Surface-water and ground-water samples were sent to the USGS National Water Quality Laboratory in Arvada, Colorado, for all analyses except bacteria. Samples were analyzed in the laboratory at the USGS office in Tucson, Arizona, for fecal coliform (FC) and fecal streptococci (FS). Analyses of surface-water samples for sediment concentration and particle-size distribution were done at the USGS sediment laboratory in Vancouver, Washington. Analyses of water samples for inorganic and organic constituents were done using procedures of Fishman and Friedman (1989) and Wershaw and others (1987), respectively.

Surface-water and ground-water analyses were compared with U.S. Environmental Protection Agency (USEPA) primary and secondary drinking water regulations (U.S. Environmental Protection Agency, 1994a, b) and State of Arizona aquifer water-quality standards (State of Arizona, 1994), which are given in table 1. Comparisons were made to determine the quality of surface water that potentially could be used for ground-water recharge and to determine variations in ground-water quality during 1994 and changes in 


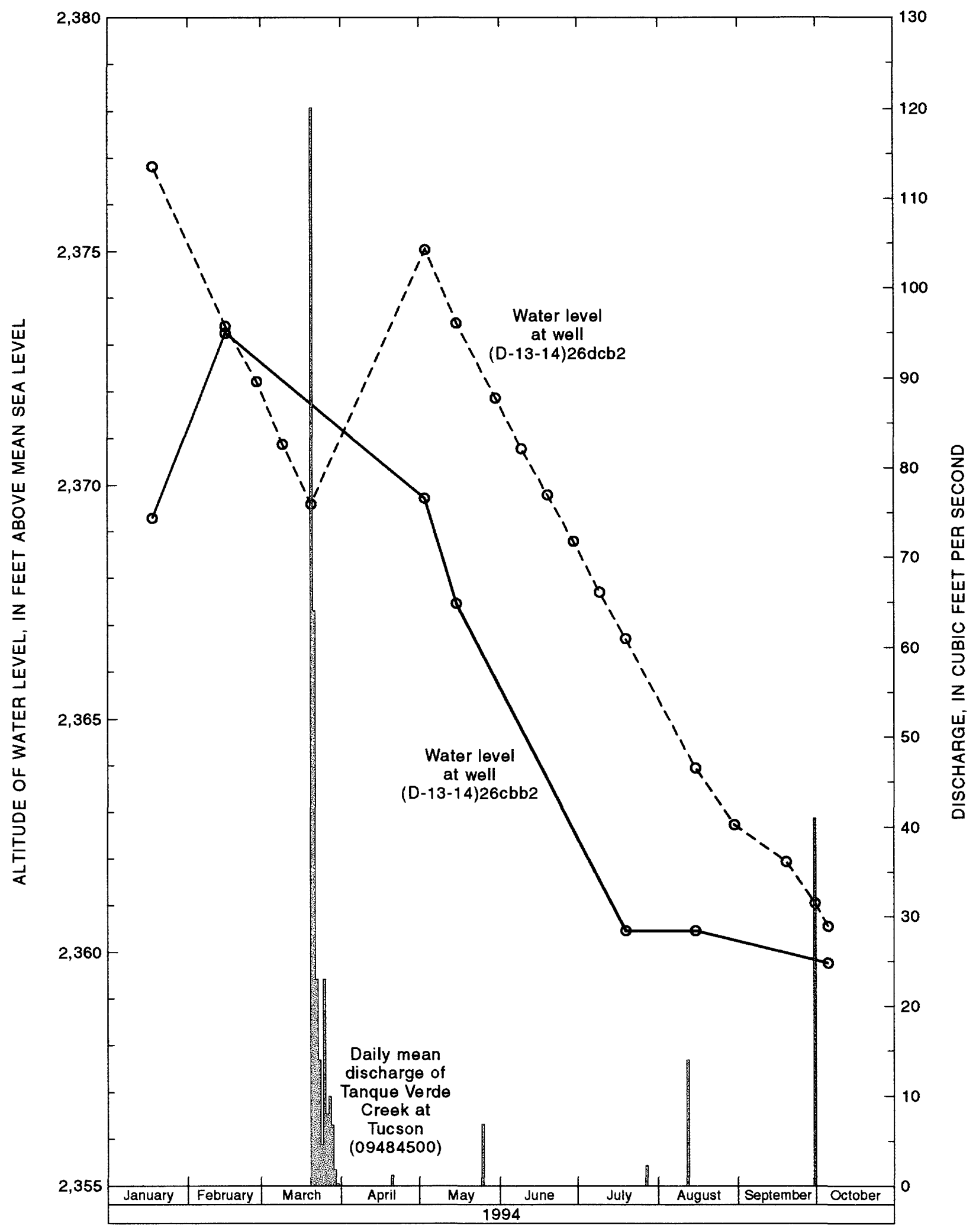

Figure 3. Flow in Tanque Verde Creek and water levels in monitoring wells (D-13-14)26cbb2 and (D-13-14)26dcb2, 1994. 


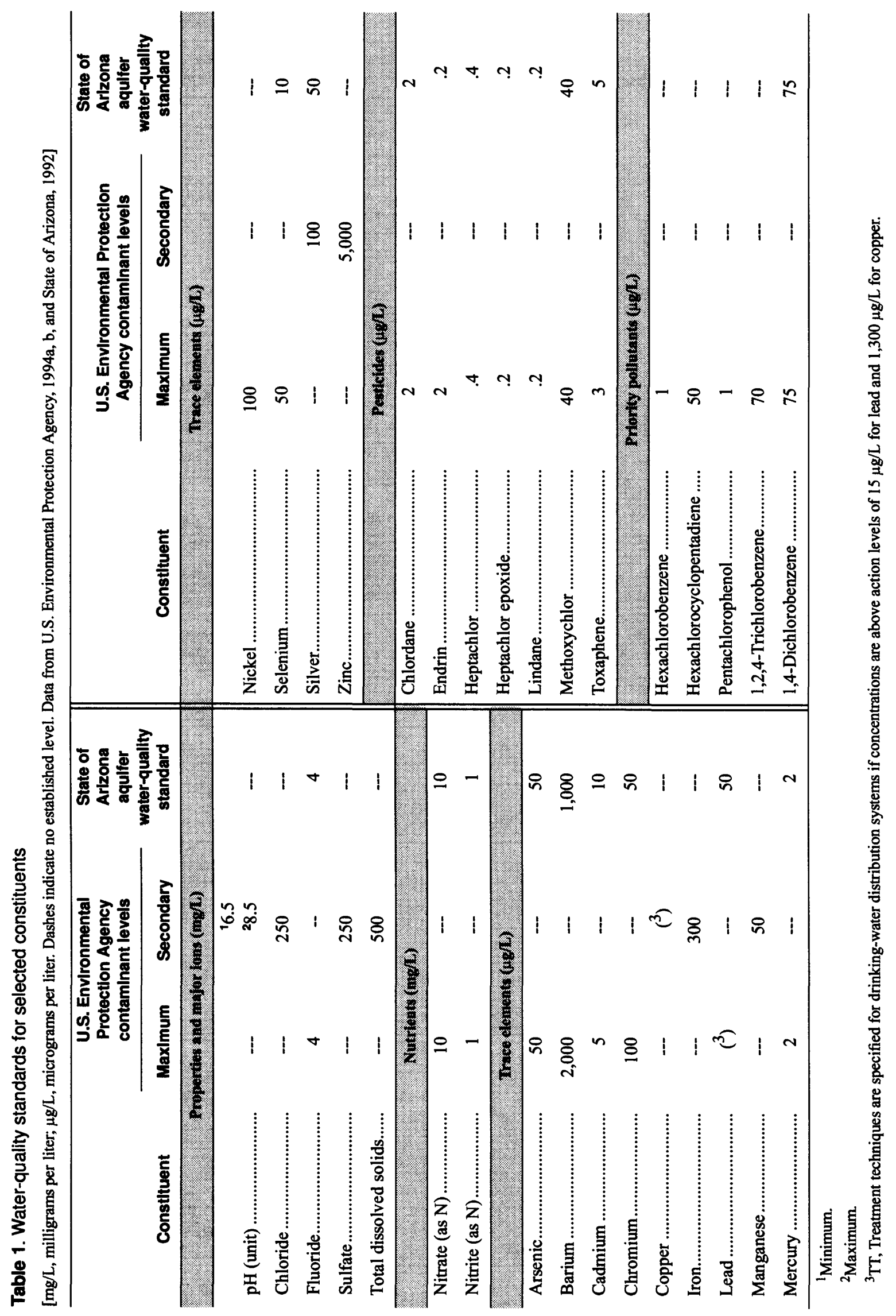


surface-water and ground-water quality that have occurred since samples were collected during 1987-93. Surface-water analyses include suspended sediment, properties, major ions, nutrients, organic carbon, trace elements, organochlorine pesticides, and priority pollutants (tables 2 and 3 in the "Basic Data" section at the back of the report). Ground-water analyses include properties, major ions, nutrients, organic carbon, bacteria, trace elements, organochlorine pesticides, and priority pollutants (table 4 in the "Basic Data" section at the back of the report).

\section{QUALITY OF SURFACE WATER}

The chemical composition of natural water is derived from many different sources of solutes including gases and aerosols from the atmosphere, weathering and erosion of rocks and soil, solution reactions occurring below the land surface, and anthropogenic activities (Hem, 1989). The quality of surface water in the study area varies from storm to storm because of variation in duration, location, intensity, and temporal distribution of precipitation within the watershed. The variability of these factors is high in the Rillito Creek watershed, which receives runoff from the intense localized thunderstorms of short duration in the summer and from less intense, areally extensive frontal storms of longer duration in the winter.

Suspended-sediment movement in streams is an important factor in the transport of many inorganic, organic, and biological contaminants. Suspended sediment may cause clogging in the channel bed during recharge, which reduces infiltration rates. Concentrations of suspended sediment were $12,357 \mathrm{mg} / \mathrm{L}$ at Tanque Verde Creek and $411 \mathrm{mg} / \mathrm{L}$ at Alamo Wash. The sediment was 94 and 98 percent silt and clay, respectively. The turbidity of 590 nephelometric-turbidity units (NTU) was significantly higher in the sample collected from Tanque Verde Creek than in the sample collected from Alamo Wash (130 NTU). The greater turbidity at Tanque Verde Creek probably resulted from larger suspended-sediment concentrations.

Values of specific conductance were $160 \mu \mathrm{S} / \mathrm{cm}$ at Tanque Verde Creek and $124 \mu \mathrm{S} / \mathrm{cm}$ at Alamo Wash. According to Hem (1989), water with a hardness of less than $60 \mathrm{mg} / \mathrm{L}$ as calcium carbonate $\left(\mathrm{CaCO}_{3}\right)$ is soft, 61 to $120 \mathrm{mg} / \mathrm{L}$ is moderately hard, 121 to $180 \mathrm{mg} / \mathrm{L}$ is hard, and more than $180 \mathrm{mg} / \mathrm{L}$ is very hard. Hardness values of 48 and $35 \mathrm{mg} / \mathrm{L}$ as $\mathrm{CaCO}_{3}$ in samples collected from Tanque Verde Creek and Alamo Wash, respectively, indicate that the surface water in the study area is soft. The largest concentrations of calcium $(16 \mathrm{mg} / \mathrm{L})$ and bicarbonate $(63 \mathrm{mg} / \mathrm{L})$ as $\mathrm{HCO}_{3}$ were found in the sample collected from Tanque Verde Creek. Concentrations of dissolved solids were $99 \mathrm{mg} / \mathrm{L}$ at Tanque Verde Creek and $83 \mathrm{mg} / \mathrm{L}$ at Alamo Wash. Calcium was the dominant cation, and bicarbonate was the dominant anion in surface-water samples (fig. 4).

Nitrogen was predominantly in surface water as nitrate. Concentrations of nitrite $(0.06 \mathrm{mg} / \mathrm{L})$, nitrite plus nitrate $(0.55 \mathrm{mg} / \mathrm{L})$, and ammonia $(0.48 \mathrm{mg} / \mathrm{L})$ were largest in samples collected from Alamo Wash. Concentrations of dissolved organic carbon were $16 \mathrm{mg} / \mathrm{L}$ at Tanque Verde Creek and $13 \mathrm{mg} / \mathrm{L}$ at Alamo Wash.

The largest concentrations of arsenic, barium, boron, copper, and iron were 2, 15, 30, 20, and $260 \mu \mathrm{g} / \mathrm{L}$, respectively. The largest concentrations of lead, manganese, molybdenum, nickel, vanadium, and zinc were $2,21,2,2,8$, and $17 \mu \mathrm{g} / \mathrm{L}$, respectively. Cadmium, chromium, silver, and selenium were not found in any of the samples. Data from Tanque Verde Creek and Alamo Wash indicate that properties, major ions, nutrients, and trace elements in samples collected in 1994 were within the same range of values as samples collected during 1987-93 (Tadayon and Smith, 1994; Tadayon, 1995).

Dieldrin and biphenyl polychlor were the only organochlorine pesticides found in surface-water samples collected in 1994 and were at the minimum reporting levels for the analytical method in the sample from Alamo Wash. Multiple organochlorine pesticides were found in small concentrations in samples collected from Alamo Wash during 1987-93 (Tadayon and Smith, 1994; Tadayon, 1995). Pesticides that were found in one or more samples from Alamo Wash during 1987-93 were aldrin, chlordane, dichlorodiphenyldichloroethane (DDD), dichlorodiphenyl ethylene (DDE), dichlorodiphenyltrichloroethane (DDT), dieldrin, endrin, and polychlorinated 


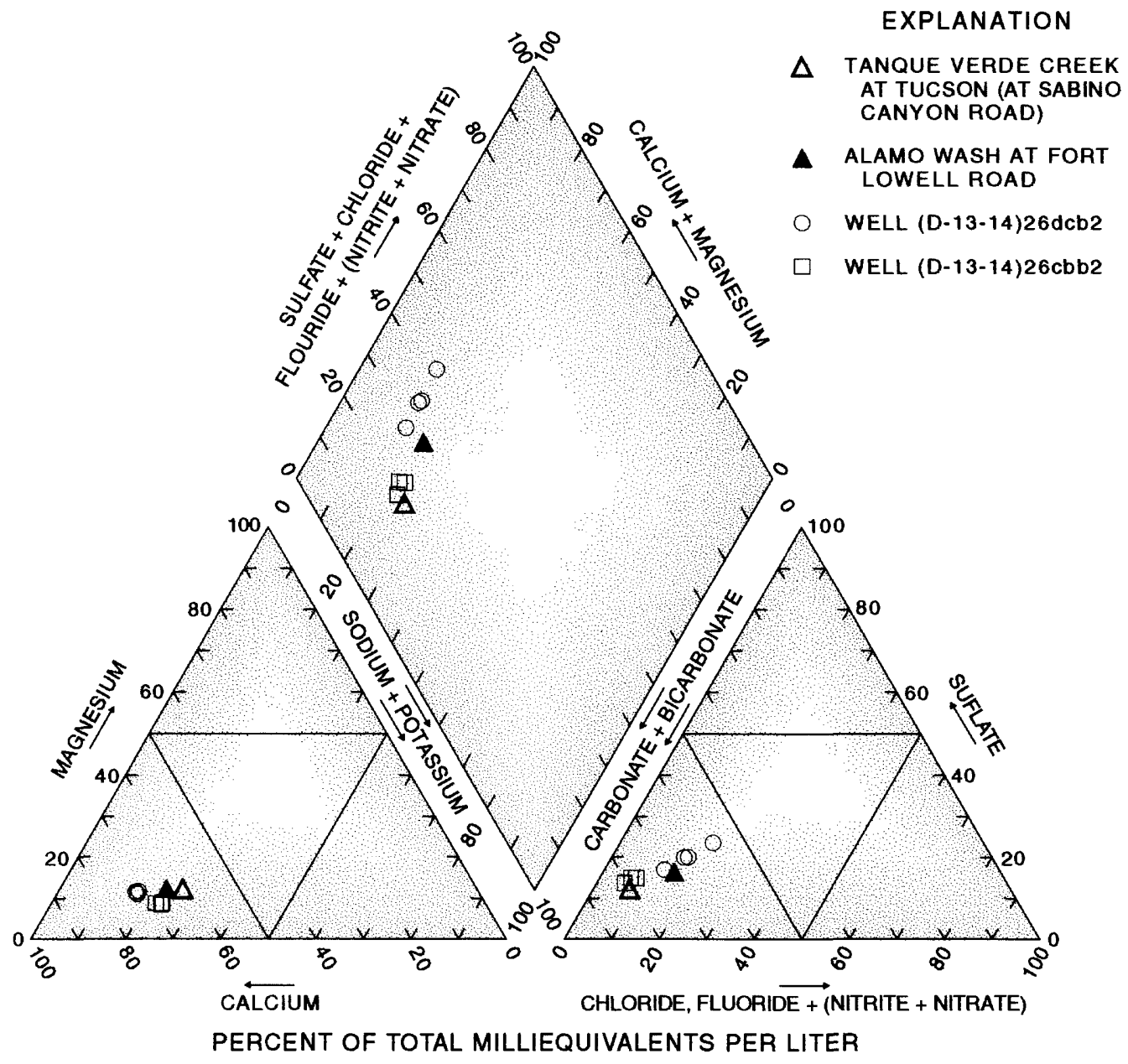

Figure 4. Compositions of surface water and ground water in the proposed artificialrecharge project area, Rillito Creek basin, Tucson, Arizona, 1994.

biphenyls (PCB's). Chlordane was only found in one sample from Tanque Verde Creek in July 1990 (Tadayon and Smith, 1994). Some of the pesticides in the water may have resulted from the use of chemicals to control weeds and insects in urban areas. Priority pollutants were not found in surface-water samples collected in 1994. Bis(2-ethylhexyl)phthalate, benzo-(b)fluoranthene, fluoranthene, and pyrene were found in one or more samples collected from Alamo Wash during 1987-93 (Tadayon and Smith, 1994; Tadayon, 1995). None of the constituent concentrations in surface water exceeded the USEPA primary maximum contaminant levels (MCL's) or secondary maximum contaminant levels (SMCL's) for drinking water or State of Arizona aquifer water-quality standards.

\section{QUALITY OF GROUND WATER}

The chemical composition of ground water is affected by streamflow recharge, underflow, geology, mineralogy, and internal and external basin-drainage patterns (Robertson, 1991). Recharge water infiltrating the unsaturated zone may undergo many physical, chemical, and biological processes (Crites, 1985; Knorr and Client, 1985; Mackay and others, 1985; and Oaksford, 1985). Such processes may include dissolution; ion exchange; adsorption; filtration; precipitation; volatilization; and physical, chemical, and microbial degradation (Miller and Blair, 1971; DeCook and Wilson, 1980; Mooradian, 1983; Olson, 1987).

Samples collected in January had larger $\mathrm{pH}$ values than samples collected during the rest of the 
year. The $\mathrm{pH}$ ranged from 6.8 to 7.4 at well (D-13-14)26cbb2 and from 6.2 to 7.1 at well (D-13-14)26dcb2. The value of 6.2 in the sample collected in July from well (D-13-14)26dcb2 was below the USEPA SMCL minimum. The largest values of specific conductance $(332 \mu \mathrm{S} / \mathrm{cm})$ and dissolved-solids concentration $(222 \mathrm{mg} / \mathrm{L})$ were found in samples collected at well (D-13-14)26cbb2 in January 1994. The largest values of hardness $(130 \mathrm{mg} / \mathrm{L})$ as $\mathrm{CaCO}_{3}$ and alkalinity $(144 \mathrm{mg} / \mathrm{L})$ as $\mathrm{CaCO}_{3}$ were found in samples from well (D-13-14)26cbb2 in January and July 1994, and July 1994, respectively. Data indicate that the water from well (D-13-14) $26 \mathrm{dcb} 2$ was moderately hard for all the samples analyzed, and water from well (D-13-14)26cbb2 was moderately hard in May and October 1994 and hard in January and July 1994 (table 4). In 1994, concentrations of dissolved solids ranged from 208 to $222 \mathrm{mg} / \mathrm{L}$ in samples from well (D-13-14)26cbb2 and ranged from 148 to $201 \mathrm{mg} / \mathrm{L}$ in samples from well (D-13-14)26dcb2. For March 1989 and January and September 1993, concentrations of dissolved solids ranged from 146 to $151 \mathrm{mg} / \mathrm{L}$ at well (D-13-14)26cbb2 and ranged from 190 to $248 \mathrm{mg} / \mathrm{L}$ at well (D-13-14)26dcb2 (Tadayon and Smith, 1994; Tadayon, 1995).

Concentrations of calcium, sodium, and bicarbonate were larger in samples from well (D-13-14)26cbb2 than in samples from well (D-13-14)26dcb2. No significant variations were found in the values of these constituents collected at different times of the year from the two monitoring wells in 1994. Concentrations of calcium and sodium in ground-water samples ranged from 32 to $47 \mathrm{mg} / \mathrm{L}$ and from 8 to $18 \mathrm{mg} / \mathrm{L}$, respectively. Concentrations of magnesium and potassium ranged from 2.9 to $3.9 \mathrm{mg} / \mathrm{L}$ and from 1.0 to $1.4 \mathrm{mg} / \mathrm{L}$, respectively. Concentrations of bicarbonate as $\mathrm{CaCO}_{3}$ ranged from 149 to $176 \mathrm{mg} / \mathrm{L}$ at well (D-13-14)26cbb2 and ranged from 90 to $107 \mathrm{mg} / \mathrm{L}$ at well (D-13-14)26dcb2. Concentrations of sulfate ranged from 21 to $23 \mathrm{mg} / \mathrm{L}$ in samples from well (D-13-14)26cbb2 and ranged from 20 to $29 \mathrm{mg} / \mathrm{L}$ in samples from well (D-13-14)26dcb2. Concentrations of chloride ranged from 3.6 to $4.7 \mathrm{mg} / \mathrm{L}$ in samples from well (D-13-14)26cbb2 and ranged from 8.5 to $12 \mathrm{mg} / \mathrm{L}$ in samples from well (D-13-14)26dcb2.
Concentrations of fluoride ranged from 0.1 to $0.2 \mathrm{mg} / \mathrm{L}$ in samples from well (D-13-14)26cbb2 and were $0.2 \mathrm{mg} / \mathrm{L}$ in all samples from well (D-13-14)26dcb2. Concentrations of silica were larger in samples from well (D-13-14)26cbb2 than in samples from well (D-13-14)26dcb2 and ranged from 30 to $35 \mathrm{mg} / \mathrm{L}$ and from 17 to $19 \mathrm{mg} / \mathrm{L}$, respectively. Calcium and sodium were the dominant cations, and bicarbonate was the dominant anion in ground-water samples (fig. 4). Concentrations of major ions in ground-water samples collected in 1994 generally were similar to concentrations in samples collected in March 1989 and January and September 1993 (Tadayon and Smith, 1994; Tadayon, 1995).

In water from the monitoring wells, nitrogen was found predominantly as nitrate. Concentrations of dissolved nitrite were below the minimum reporting level for the analytical method except in one sample from well (D-13-14)26dcb2 in October 1994 in which the concentration was at the minimum reporting level $(0.01 \mathrm{mg} / \mathrm{L})$. The concentration of nitrite plus nitrate $(2.2 \mathrm{mg} / \mathrm{L})$ was largest in well (D-13-14)26cbb2 in January 1994 and was smallest $(0.92 \mathrm{mg} / \mathrm{L})$ in well (D-13-14)26dcb2 in July 1994. Orthophosphorus was not found in any of the samples collected from the monitoring wells in 1994. Small concentrations of nutrients were found in ground-water samples collected in March 1989 and January and September 1993 (Tadayon and Smith, 1994; Tadayon, 1995). The concentrations of dissolved organic carbon were largest in samples collected in October 1994. Concentrations of dissolved organic carbon ranged from 0.7 to $4.8 \mathrm{mg} / \mathrm{L}$ in samples from well (D-13-14)26cbb2 and ranged from 1.8 to $2.8 \mathrm{mg} / \mathrm{L}$ in samples from well (D-13-14) $26 \mathrm{dcb} 2$. Concentrations of dissolved organic carbon ranged from 0.7 to $2.3 \mathrm{mg} / \mathrm{L}$ in samples for the same monitoring wells in March 1989 and January and September 1993 (Tadayon and Smith, 1994; Tadayon, 1995).

Fecal coliform are bacteria that are present in the intestines or feces of warm-blooded animals and commonly are used as indicators of the sanitary quality of the water. Fecal streptococci also are bacteria found in the intestines of warmblooded animals, and the presence of fecal streptococci verifies fecal pollution. The densities of fecal coliform and fecal streptococci show wide 
fluctuation throughout the year in samples collected from the monitoring wells. Fecal coliform were not found in samples from well (D-13-14)26cbb2 collected in July and were present at $240 \mathrm{col} / 100 \mathrm{~mL}$ in samples collected in October. Fecal coliform ranged from $2 \mathrm{col} / 100 \mathrm{~mL}$ in samples collected from well (D-13-14)26dcb2 in May to about $500 \mathrm{col} / 100 \mathrm{~mL}$ in samples collected in October. Fecal streptococci were not found in samples from well (D-13-14)26cbb2 collected in July and were present at more than $500 \mathrm{col} / 100 \mathrm{~mL}$ in samples collected in January, May, and October. Fecal streptococci ranged from $71 \mathrm{col} / 100 \mathrm{~mL}$ in samples from well (D-13-14)26dcb2 collected in January to more than $500 \mathrm{col} / 100 \mathrm{~mL}$ in samples collected in May and October.

Concentrations of barium $(54 \mu \mathrm{g} / \mathrm{L})$, boron $(40 \mu \mathrm{g} / \mathrm{L})$, copper $(60 \mu \mathrm{g} / \mathrm{L})$, manganese $(230 \mu \mathrm{g} / \mathrm{L})$, nickel $(3 \mu \mathrm{g} / \mathrm{L})$, and zinc $(35 \mu \mathrm{g} / \mathrm{L})$ were larger in ground-water samples than in surface-water samples. Concentrations of manganese ranged from 60 to $110 \mu \mathrm{g} / \mathrm{L}$ in well (D-13-14)26cbb2 and ranged from 110 to $230 \mu \mathrm{g} / \mathrm{L}$ in well (D-13-14)26dcb2. Concentrations of manganese in the ground-water samples exceeded the USEPA SMCL of $50 \mu \mathrm{g} / \mathrm{L}$. Concentrations of trace elements in ground-water samples did not exceed any of the USEPA MCL's or State of Arizona aquifer water-quality standards. Cadmium, chromium, lead, molybdenum, silver, and selenium were not found in ground-water samples. Concentrations of trace elements in samples from the monitoring wells did not vary significantly throughout the year and were not significantly different from concentrations in samples collected in March 1989 and January and September 1993 (Tadayon and Smith, 1994; Tadayon, 1995).

Organochlorine pesticides and priority pollutants were not found in ground-water samples collected in 1994. One sample from well (D-13-14)26cbb2, collected on January 19, 1994, was not analyzed because the bottle was broken during shipment to the laboratory. Organochlorine pesticides and priority pollutants were not found in samples collected from the monitoring wells (D-13-14)26cbb2 and (D-13-14)26dcb2 in March 1989 and January and September 1993 (Tadayon and Smith, 1994; Tadayon, 1995).

\section{SUMMARY}

Controlled artificial recharge of surface runoff is being considered as a water-management technique to address the problem of ground-water overdraft in the Tucson basin. The planned use of recharge facilities in urban areas has caused concern about the quality of runoff to be recharged and the potential for ground-water contamination. The proposed recharge facility in Rillito Creek will utilize runoff entering a 1-mile reach of the Rillito Creek between Craycroft Road and Swan Road for infiltration and recharge purposes within the channel and excavated overbank areas.

Physical and chemical data were collected from two surface-water and two ground-water sites in 1994. Surface-water samples were collected from Tanque Verde Creek in September 1994 and from Alamo Wash in May 1994 and were analyzed to determine the occurrence and concentrations of potential contaminants in water and changes in quality since samples were collected during 1987-93. The quality of surface water varies from storm to storm because of variation in the duration, location, intensity, and temporal distribution of precipitation within the watershed. The variability of these factors is high in the Rillito Creek watershed, which receives runoff from the intense localized thunderstorms of short duration in the summer and from less intense, areally extensive frontal storms of longer duration in the winter. Ground-water samples were collected from monitoring wells (D-13-14)26cbb2 and (D-13-14)26dcb2 in January, May, July, and October 1994 to determine the variability of ground-water quality throughout the year and changes in quality since samples were collected in 1989 and 1993.

Data from Tanque Verde Creek and Alamo Wash indicate that surface water is soft and that the water is a calcium bicarbonate type. Nitrogen was detected predominantly as nitrate and concentrations of dissolved nitrite, nitrite plus nitrate, and ammonia were small at the two sampling sites. Values for properties and concentrations of nutrients and trace elements in samples collected in 1994 from Tanque Verde Creek and Alamo Wash were within the range of values for samples collected during 1987-93. 
Dieldrin and biphenyl polychlor were the only organochlorine pesticides found in surface-water samples collected in 1994 and were at the minimum reporting levels in the sample from Alamo Wash. None of the constituents analyzed in surface water exceeded the USEPA MCL's or SMCL's, or State of Arizona aquifer water-quality standards.

In the ground-water samples, values of specific conductance, hardness, alkalinity, and dissolvedsolids concentration were largest in samples from well (D-13-14)26cbb2. The data indicated that the water from well (D-13-14)26cbb2 is moderately hard to hard and water from well (D-13-14)26dcb2 is moderately hard. The $\mathrm{pH}$ of one sample from (D-13-14)26dcb2 was less than the USEPA SMCL minimum. Concentrations of calcium, sodium, and bicarbonate were larger in samples from well (D-13-14)26cbb2 than in samples from well (D-13-14)26dcb2. In ground water, calcium and sodium were the dominant cations, and bicarbonate was the dominant anion. Concentrations of major ions in ground water from the monitoring wells did not vary significantly throughout the year and were similar to concentrations in samples collected in March 1989 and January and September 1993.

Nitrogen was found in ground water predominantly as nitrate. The largest concentration of dissolved organic carbon was found in samples collected from the monitoring wells in October 1994. The densities of fecal coliform and fecal streptococci showed wide variations in samples collected from monitoring wells (D-13-14)26cbb2 and (D-13-14)26dcb2 throughout the year. Concentrations of manganese in the ground-water samples exceeded the USEPA SMCL of $50 \mu \mathrm{g} / \mathrm{L}$. None of the dissolved trace elements exceeded the USEPA MCL's or State of Arizona aquifer water-quality standards. Concentrations of dissolved trace elements in samples from the monitoring wells did not vary significantly throughout the year. Organochlorine pesticides and priority pollutants were not found in ground-water samples collected in 1994.
SELECTED REFERENCES

Barnes, R.L., 1988, Basic ground-water data for the Rillito River recharge project: State of Arizona Department of Water Resources Open-File Report 5, $38 \mathrm{p}$.

Burkham, D.E., 1970, Depletion of streamflow by infiltration in the main channels of the Tucson basin, southern Arizona: U.S. Geological Survey Water-Supply Paper 1939-B, 36 p.

Camp Dresser \& McKee, Inc., 1990, Rillito Creek recharge feasibility study, water sources, hydrogeology and water quality: Camp Dresser \& McKee, Inc., Rillito Project Management Committee, Phase A, Tasks 1, 2, 3, and 4, v.p.

CH2M Hill, 1988a, Tucson Water, Phase A, Tucson recharge feasibility assessment-Task 5, Hydrogeological evaluations for recharge sites: Tucson, Arizona, CH2M Hill report, $102 \mathrm{p}$. 1988b, Tucson Water, Phase A, Tucson recharge feasibility assessment-Task 6, Water source evaluation for recharge sites: Tucson, Arizona, CH2M Hill report, v.p.

1992, Rillito recharge project report-Preliminary design report: Tucson, Arizona, CH2M Hill report, $47 \mathrm{p}$.

Condes de La Torre, Alberto, 1970, Streamflow in the upper Santa Cruz River basin, Santa Cruz and Pima Counties, Arizona: U.S. Geological Survey Water-Supply Paper 1939-A, 26 p.

Crites, R.W., 1985, Micropollutant removal in rapid infiltration, in Asano, Takashi, ed., Artificial Recharge of Groundwater: Boston, Massachusetts, Butterworth Publishers, p. 579-609.

Davidson, E.S., 1973, Geohydrology and water resources of the Tucson basin, Arizona: U.S. Geological Survey Water-Supply Paper 1939-E, $81 \mathrm{p}$.

DeCook, K.J., and Wilson, L.G., 1980, Ground-water recharge from urban runoff and irrigation returns, in Proceedings of the Deep Percolation Symposium: Phoenix, Arizona Department of Water Resources Report No. 1, Scottsdale, Arizona, May 1-2, 1980, p. 37-52.

Fishman, M.J., and Friedman, L.C., eds., 1989, Methods for determination of inorganic substances in water and fluvial sediment: U.S. Geological Survey Techniques of Water-Resources Investigations, book 5 , chap. A1, $545 \mathrm{p}$.

Garrett, J.M., and Gellenbeck, D.J., 1991, Basin characteristics and streamflow statistics in Arizona as of 1989: U.S. Geological Survey 
Water-Resources Investigations Report 91-4041, $612 \mathrm{p}$.

Knorr, D.B., and Cliett, Tom, 1985, Proposed groundwater recharge at El Paso, Texas, in Asano, Takashi, ed., Artificial Recharge of Groundwater: Boston, Massachusetts, Butterworth Publishers, p. $425-480$.

MacKay, D.M., Roberts, P.V., and Cherry, J.A., 1985, Transport of organic contaminants in ground water: Environmental Science Technology, v. 19, no. 5, p. 384-392.

Matlock, W.G., 1965, The effect of silt-laden water on infiltration in alluvial channels: Tucson, Arizona, University of Arizona, doctoral dissertation, $102 \mathrm{p}$.

Miller, D.G., and Blair, A.H., 1971, The principles and practice of pretreatment for artificial recharge, in Artificial Groundwater Recharge: Buckinghamshire, England, The Water Research Association Proceedings, University of Reading, England, September 21-24, 1970, v. 1, p. 83-109.

Mooradian, M.M., 1983, The Ina Road landfill as a source of ground-water pollution: Tucson, Arizona, University of Arizona, master's thesis, $86 \mathrm{p}$.

Oaksford, E.T., 1985, Artificial recharge-Methods, hydraulics, and monitoring, in Asano, Takashi, ed., Artificial Recharge of Groundwater: Boston, Massachusetts, Butterworth Publishers, p. 69-127.

Olson, K.L., 1987, Urban stormwater injection via dry wells in Tucson, Arizona, and its effect on ground-water quality: Tucson, Arizona, University of Arizona master's thesis, $151 \mathrm{p}$.

Pima County Department of Transportation and Flood Control District, 1986, Rillito Creek groundwater recharge/flood storage/natural riverine preservation project-A proposal for environmental monitoring program to High Plains States Groundwater Demonstration Program Act of 1983: Pima County Department of Transportation and Flood Control District, Pima County, Arizona, 111 p.

Robertson, F.N., 1991, Geochemistry of ground water in alluvial basins of Arizona and adjacent parts of Nevada, New Mexico, and California: U.S. Geological Survey Professional Paper 1406-C, $90 \mathrm{p}$.

State of Arizona, 1992, Aquifer water-quality standards: Phoenix, Arizona, State of Arizona, Arizona Administrative Code, Title 18, Chapter 11, R-18-11-406, Supplement 92-4, p. 37-38.
Tadayon, Saeid, 1995, Quality of water and chemistry of bottom sediment in the Rillito Creek basin, Tucson, Arizona, 1992-93: U.S. Geological Survey Water-Resources Investigations Report 95-4062, $57 \mathrm{p}$.

Tadayon, Saeid, and Smith, C.F., 1994, Quality of water and chemistry of bottom sediment in the Rillito Creek basin, Tucson, Arizona, 1986-92: U.S. Geological Survey Water-Resources Investigations Report 94-4114, 90 p.

U.S. Department of Commerce, 1994, Climatological data, annual summary, Arizona, 1994: National Oceanic and Atmospheric Administration, v. 98, no. $13,26 \mathrm{p}$.

U.S. Environmental Protection Agency, 1994a, National revised primary drinking water regulationsMaximum contaminant levels: Title 40, Subpart G, sections 141.61-141.63, July 1, 1994, p. 750-754.

1994b, National secondary drinking water regulations: Title 40, part 143, section 143.3, July 1, 1994, p. 836.

U.S. Geological Survey, 1976, Water resources data for Arizona, water year 1975: U.S. Geological Survey Water Data Report AZ-75-1, 404 p.

1977, National handbook of recommended methods for water-data acquisition-Chapter 5, Chemical and physical quality of water and sediment: Washington, D.C., U.S. Geological Survey, Office of Water-Data Coordination, $193 \mathrm{p}$.

1985, Water-quality laboratory services catalog: U.S. Geological Survey Open-File Report 85-171, 5 parts, v.p.

Wershaw, R.L., Fishman, M.J., Grabbe, R.R., and Lowe, L.E., 1987, Methods for the determination of organic substances in water and fluvial sediments: U.S. Geological Survey Techniques of Water Resources Investigations, book 5, chap. A3, 80 p. 
Table 2. Suspended-sediment concentration and particle-size distribution in surface-water samples, Rillito Creek basin

$\left[\mathrm{ft}^{3} / \mathrm{s}\right.$, cubic feet per second; $\mathrm{mg} / \mathrm{L}$, milligrams per liter; mm, millimeter; <, less than; $\geq$, equal to or greater than]

\begin{tabular}{|c|c|c|c|c|c|}
\hline \multirow[b]{2}{*}{ Date } & \multirow[b]{2}{*}{ Time } & \multirow[b]{2}{*}{$\begin{array}{c}\text { Dlscharge } \\
\left(\mathrm{ft}^{3} / \mathrm{s}\right)\end{array}$} & \multirow[b]{2}{*}{$\begin{array}{c}\text { Suspended-sediment } \\
\text { concentration } \\
(\mathbf{m g} / \mathrm{L})\end{array}$} & \multicolumn{2}{|c|}{ Particle-slze distrlbution, in percent } \\
\hline & & & & $\begin{array}{l}\text { Sllt and clay } \\
<0.062 \mathrm{~mm}\end{array}$ & $\begin{array}{c}\text { Sand and coarser } \\
\text { materlal } \\
\geq 0.062-2 \mathrm{~mm}\end{array}$ \\
\hline 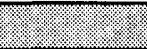 & : & 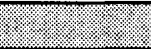 & 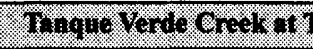 & (z) & \\
\hline $09-03-94$ & 1100 & 112 & 12,357 & 94 & 6 \\
\hline 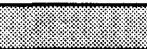 & & 1.120 & 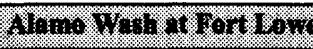 & 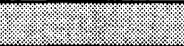 & 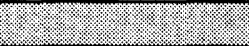 \\
\hline $05-26-94$ & 1845 & 41 & 411 & 98 & 2 \\
\hline
\end{tabular}

Table 3. Analytical results of surface-water samples, Rillito Creek basin Properties and major ions

$\left[\mathrm{ft}^{3} / \mathrm{s}\right.$, cubic feet per second; ${ }^{\circ} \mathrm{C}$, degrees Celsius; $\mu \mathrm{S} / \mathrm{cm}$, microsiemens per centimeter at $25^{\circ} \mathrm{C}$; mg/L milligrams per liter; NTU nephelometric-turbidity units; $\mu \mathrm{g} / \mathrm{L}$, micrograms per liter; $<$, less than. Dashes indicate no data]

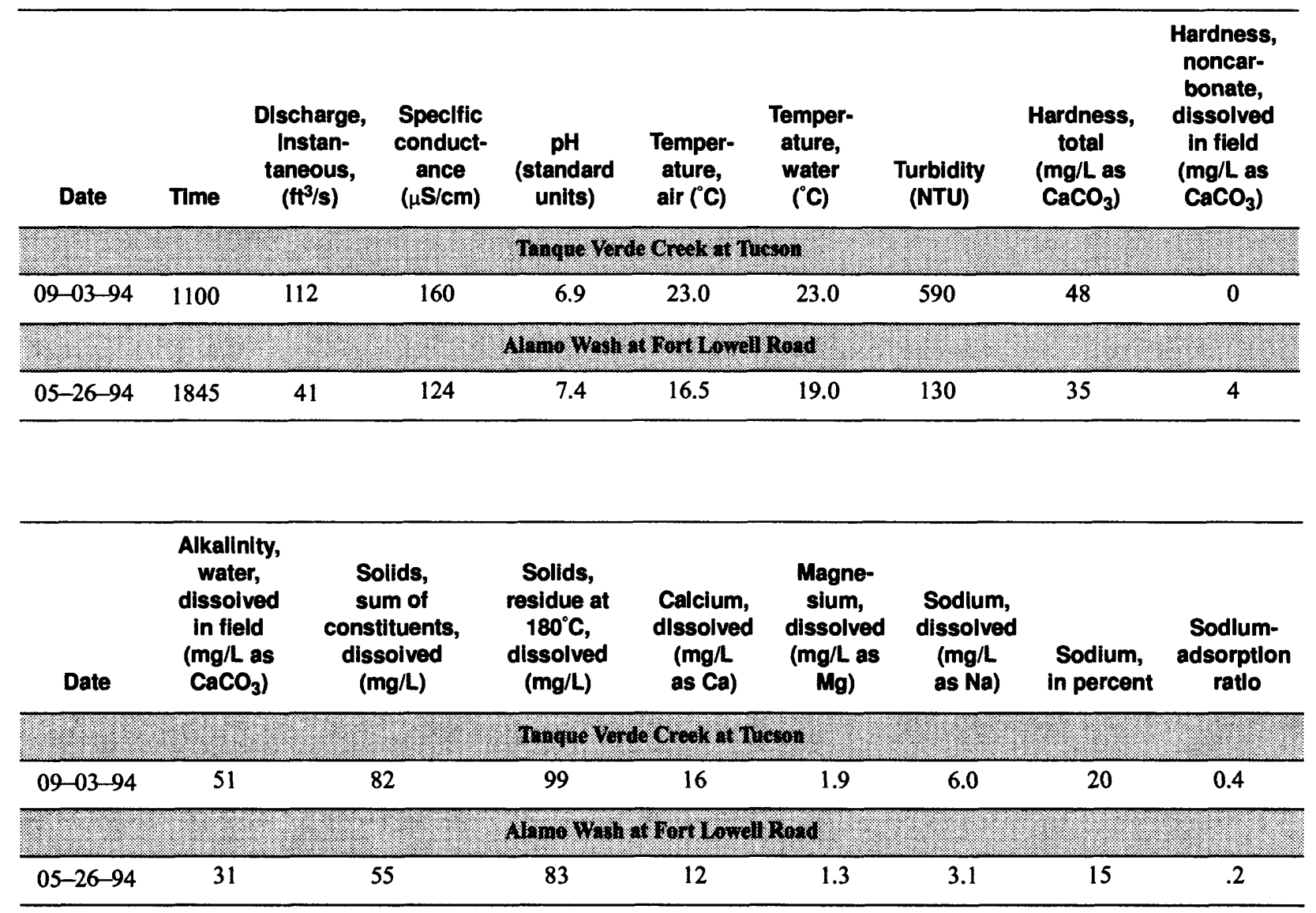


Table 3. Analytical results of surface-water samples, Rillito Creek basin-Continued

Properties and major ions-Continued

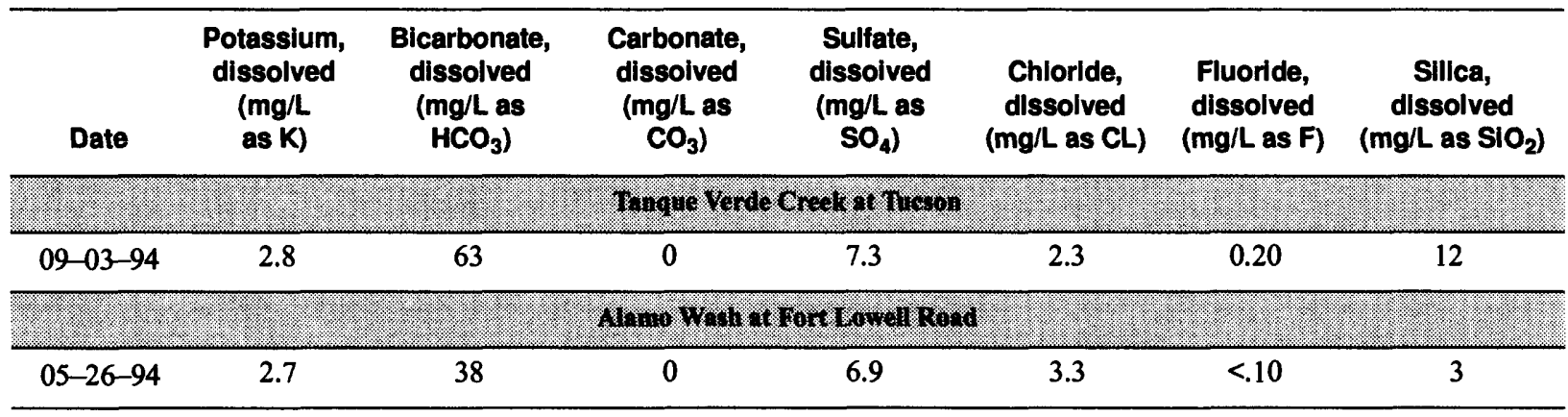

Nutrients, organic carbon, and trace elements

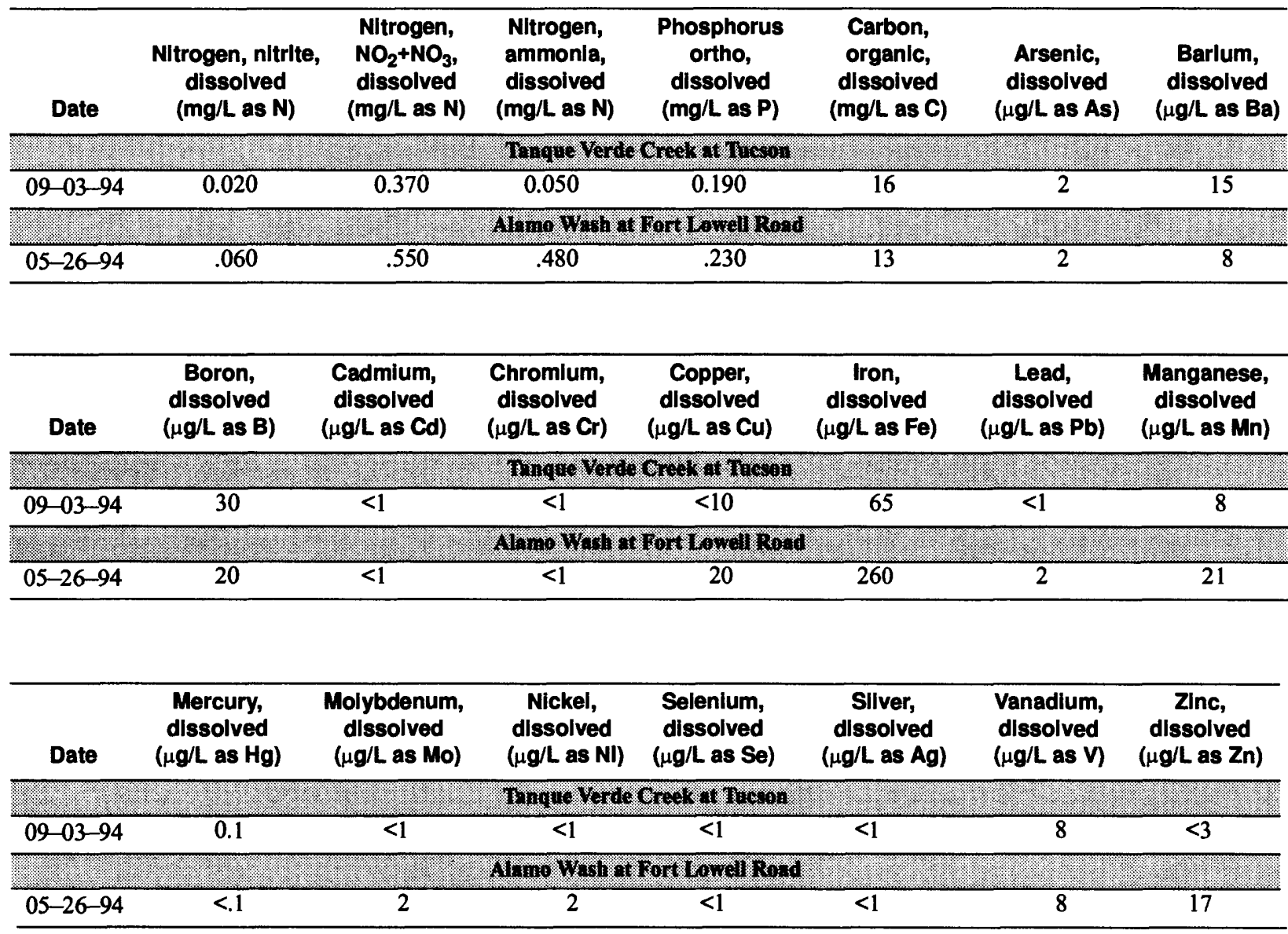


Table 3. Analytical results of surface-water samples, Rillito Creek basin-Continued Organochlorine pesticides

[DDD, dichlorodiphenyldichloroethane; DDE, dichlorodiphenylethylene; DDT, dichlorodiphenyltrichloroethane]

\begin{tabular}{|c|c|c|c|c|c|c|c|c|}
\hline Date & $\begin{array}{c}\text { Perthane, } \\
\text { total } \\
(\mu g / L)\end{array}$ & $\begin{array}{c}\text { Endosulfate, } \\
\text { total } \\
(\mu g / L)\end{array}$ & $\begin{array}{c}\text { Aldrin, } \\
\text { total } \\
(\mu g / L)\end{array}$ & $\begin{array}{c}\text { Chlordane, } \\
\text { total } \\
(\mu g / L)\end{array}$ & $\begin{array}{l}\text { DDD, } \\
\text { total } \\
(\mu g / L)\end{array}$ & $\begin{array}{l}\text { DDE, } \\
\text { total } \\
(\mu g / L)\end{array}$ & $\begin{array}{c}\text { DDT, } \\
\text { total } \\
(\mu g / L)\end{array}$ & $\begin{array}{l}\text { Dlel- } \\
\text { drln, } \\
\text { total } \\
(\mu \mathrm{g} / \mathrm{L})\end{array}$ \\
\hline \multicolumn{9}{|c|}{ 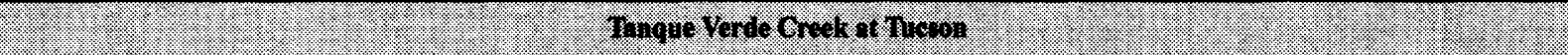 } \\
\hline $09-03-94$ & $<0.1$ & $<0.010$ & $<0.010$ & $<0.1$ & $<0.010$ & $<0.010$ & $<0.010$ & $<0.010$ \\
\hline \multicolumn{9}{|c|}{ 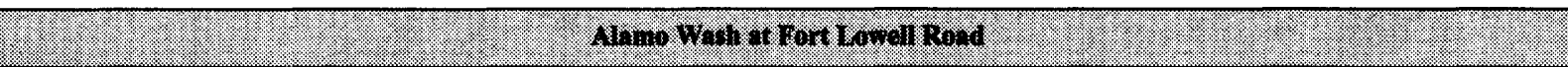 } \\
\hline $05-26-94$ & $<.1$ & $<.010$ & $<.010$ & $<.1$ & $<.010$ & $<.010$ & $<.010$ & .010 \\
\hline
\end{tabular}

\begin{tabular}{|c|c|c|c|c|c|c|c|c|c|}
\hline Date & $\begin{array}{c}\text { Endrin, } \\
\text { total } \\
(\mu g / L)\end{array}$ & $\begin{array}{l}\text { Hepta- } \\
\text { chlor, } \\
\text { total } \\
(\mu g / L)\end{array}$ & $\begin{array}{c}\text { Hepta- } \\
\text { chlor } \\
\text { epoxide, } \\
\text { total } \\
(\mu g / L)\end{array}$ & $\begin{array}{c}\text { Lindane, } \\
\text { total } \\
(\mu \mathrm{g} / \mathrm{L})\end{array}$ & $\begin{array}{c}\text { Toxa- } \\
\text { phene, } \\
\text { total } \\
(\mu g / L)\end{array}$ & $\begin{array}{c}\text { Biphenyl, } \\
\text { poly- } \\
\text { chlor, } \\
\text { total } \\
(\mu g / L)\end{array}$ & $\begin{array}{c}\text { Naph- } \\
\text { thalene, } \\
\text { poly- } \\
\text { chlor, } \\
\text { total } \\
(\mu g / L)\end{array}$ & $\begin{array}{l}\text { Meth- } \\
\text { oxy- } \\
\text { chlor, } \\
\text { total } \\
(\mu g / L)\end{array}$ & $\begin{array}{c}\text { Mirex, } \\
\text { total } \\
(\mu g / L)\end{array}$ \\
\hline \multicolumn{10}{|c|}{ 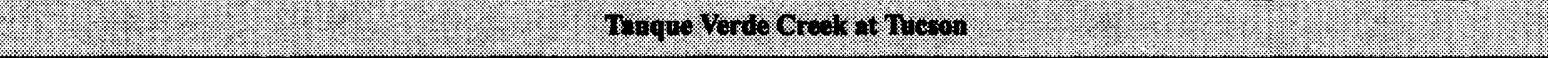 } \\
\hline $09-03-94$ & $<0.010$ & $<0.010$ & $<0.010$ & $<0.010$ & $<1$ & $<0.1$ & $<0.10$ & $<0.01$ & $<0.01$ \\
\hline 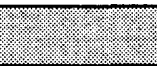 & \multicolumn{9}{|c|}{ 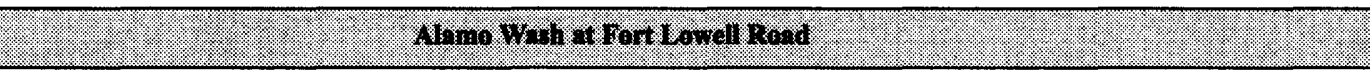 } \\
\hline $05-26-94$ & $<.010$ & $<.010$ & $<.010$ & $<.010$ & $<1$ & .1 & $<.10$ & $<.01$ & $<.01$ \\
\hline
\end{tabular}

Priority pollutants

\begin{tabular}{|c|c|c|c|c|c|c|c|}
\hline Date & $\begin{array}{c}\text { Para- } \\
\text { chloro- } \\
\text { meta } \\
\text { cresol, } \\
\text { total } \\
(\mu g / \mathrm{L})\end{array}$ & $\begin{array}{c}\text { 2- } \\
\text { Chioro- } \\
\text { phenol, } \\
\text { total } \\
(\mu \mathrm{g} / \mathrm{L})\end{array}$ & $\begin{array}{c}\text { 2,4- } \\
\text { Dichloro- } \\
\text { phenol, } \\
\text { total } \\
(\mu g / L)\end{array}$ & $\begin{array}{c}2,4,6-T r i- \\
\text { chloro- } \\
\text { phenol, } \\
\text { totai } \\
(\mu \mathrm{g} / \mathrm{L})\end{array}$ & $\begin{array}{l}\text { 2,4-Dl- } \\
\text { methyi- } \\
\text { phenol, } \\
\text { total } \\
(\mu \mathrm{g} / \mathrm{L})\end{array}$ & $\begin{array}{c}\text { 4,6-DI- } \\
\text { nitro-ortho- } \\
\text { cresol, } \\
\text { total } \\
(\mu \mathrm{g} / \mathrm{L})\end{array}$ & $\begin{array}{c}\text { 2,4-Dl- } \\
\text { nltro- } \\
\text { phenol, } \\
\text { total } \\
(\mu g / L)\end{array}$ \\
\hline \multicolumn{8}{|c|}{ 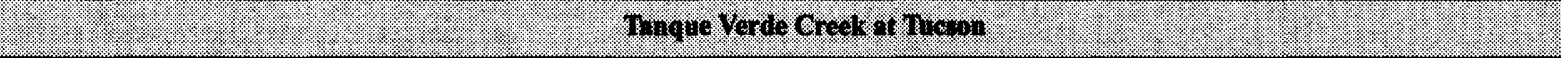 } \\
\hline $09-03-94$ & $<30.0$ & $<5.0$ & $<5.0$ & $<20.0$ & $<5.0$ & $<30.0$ & $<20.0$ \\
\hline \multicolumn{8}{|c|}{ 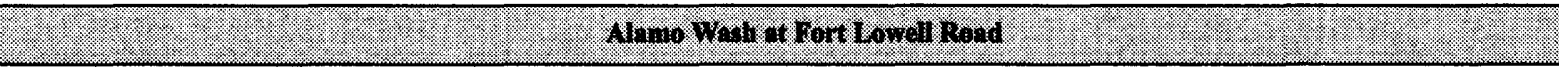 } \\
\hline $05-26-94$ & $<30.0$ & $<5.0$ & $<5.0$ & $<20.0$ & $<5.0$ & $<30.0$ & $<20.0$ \\
\hline
\end{tabular}


Table 3. Analytical results of surface-water samples, Rillito Creek basin-Continued Priority pollutants-Continued

\begin{tabular}{|c|c|c|c|c|c|c|c|c|}
\hline Date & $\begin{array}{c}\text { 2- } \\
\text { Nitro- } \\
\text { phenol, } \\
\text { total } \\
(\mu g / L)\end{array}$ & $\begin{array}{c}\text { 4-Nitro- } \\
\text { phenol, } \\
\text { totai } \\
(\mu \mathrm{g} / \mathrm{L})\end{array}$ & $\begin{array}{c}\text { Penta- } \\
\text { chioro- } \\
\text { phenol, } \\
\text { total } \\
(\mu g / L)\end{array}$ & $\begin{array}{c}\text { Phenol, } \\
\text { (C6h-50h) } \\
\text { total } \\
(\mu \mathrm{g} / \mathrm{L})\end{array}$ & $\begin{array}{c}\text { Ace- } \\
\text { naph- } \\
\text { thene, } \\
\text { total } \\
(\mu \mathrm{g} / \mathrm{L})\end{array}$ & $\begin{array}{c}\text { Ace- } \\
\text { naph- } \\
\text { thylene, } \\
\text { total } \\
(\mu g / L)\end{array}$ & $\begin{array}{l}\text { Anthra- } \\
\text { cene, } \\
\text { total } \\
(\mu g / L)\end{array}$ & $\begin{array}{c}\text { Benzidine, } \\
\text { total } \\
(\mu \mathrm{g} / \mathrm{L})\end{array}$ \\
\hline \multicolumn{9}{|c|}{ 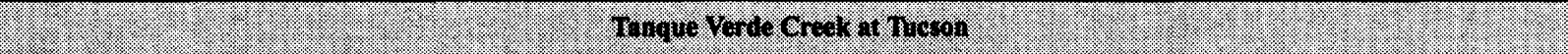 } \\
\hline $09-03-94$ & $<5.0$ & $<30.0$ & $<30.0$ & $<5.0$ & $<5.0$ & $<5.0$ & $<5.0$ & $<40.0$ \\
\hline \multicolumn{9}{|c|}{ 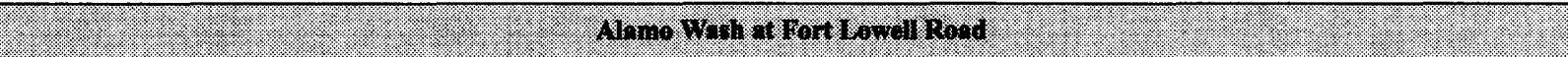 } \\
\hline $05-26-94$ & $<5.0$ & $<30.0$ & $<30.0$ & $<5.0$ & $<5.0$ & $<5.0$ & $<5.0$ & $<40.0$ \\
\hline
\end{tabular}

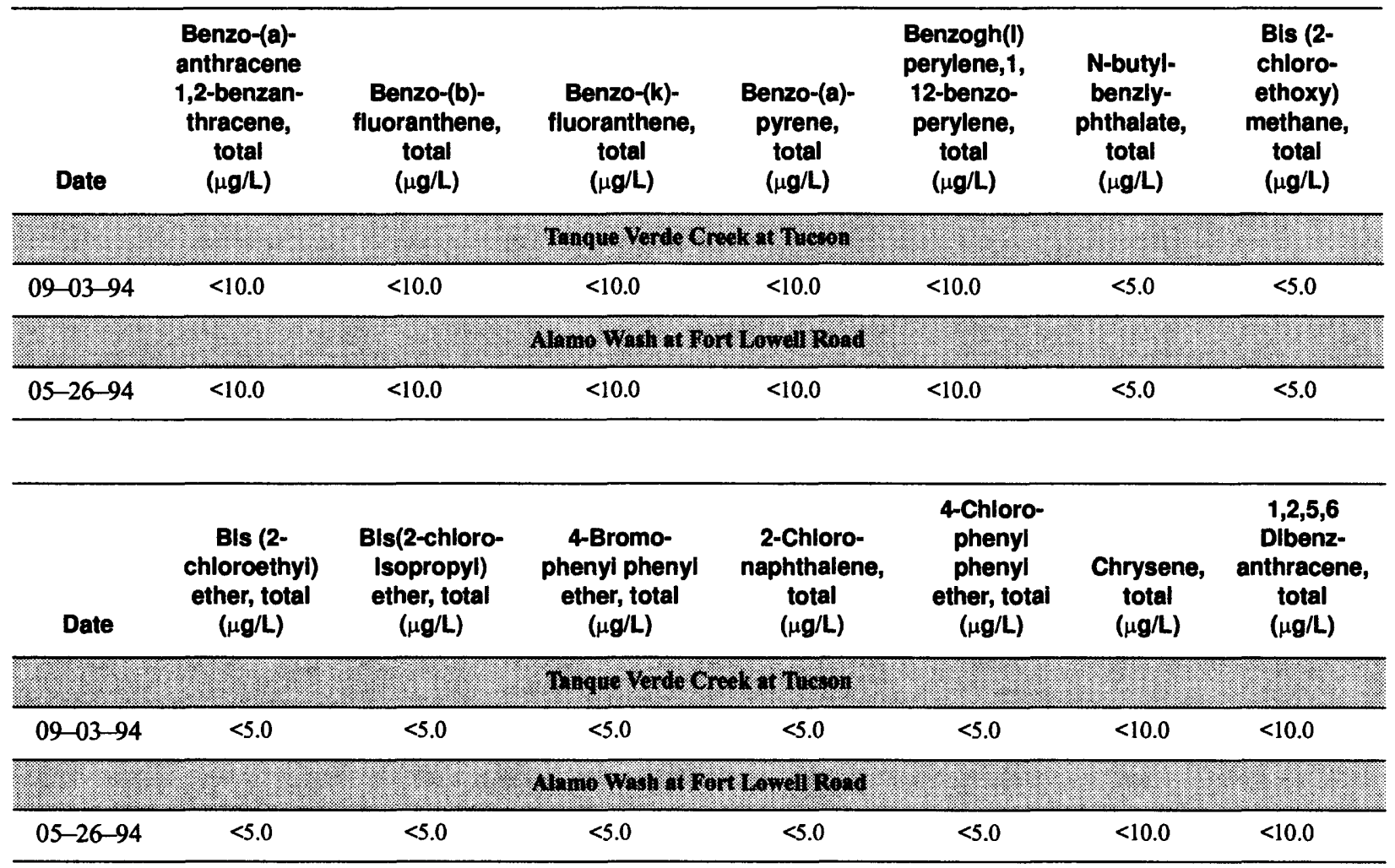

\begin{tabular}{|c|c|c|c|c|c|c|c|c|}
\hline Date & $\begin{array}{c}\text { DI-n-butyl } \\
\text { phthalate, } \\
\text { total } \\
(\mu \mathrm{g} / \mathrm{L})\end{array}$ & $\begin{array}{c}1,2- \\
\text { Chloro- } \\
\text { benzene, } \\
\text { total } \\
(\mu g / L)\end{array}$ & $\begin{array}{c}\text { 1,3-Di- } \\
\text { chloro- } \\
\text { benzene, } \\
\text { total } \\
(\mu \mathrm{g} / \mathrm{L})\end{array}$ & $\begin{array}{c}\text { 1,4-Di- } \\
\text { chloro- } \\
\text { benzene, } \\
\text { total } \\
(\mu \mathrm{g} / \mathrm{L})\end{array}$ & $\begin{array}{c}\text { 3,3-Di- } \\
\text { chloro- } \\
\text { benzidine, } \\
\text { total } \\
(\mu g / L)\end{array}$ & $\begin{array}{c}\text { Dlethyl } \\
\text { phthalate, } \\
\text { total } \\
(\mu \mathrm{g} / \mathrm{L})\end{array}$ & $\begin{array}{c}\text { DI- } \\
\text { methyl- } \\
\text { phthalate, } \\
\text { total } \\
(\mu \mathrm{g} / \mathrm{L})\end{array}$ & $\begin{array}{c}\text { 2,4-Di- } \\
\text { nitro- } \\
\text { toluene, } \\
\text { totai } \\
(\mu \mathrm{g} / \mathrm{L})\end{array}$ \\
\hline \multicolumn{9}{|c|}{ 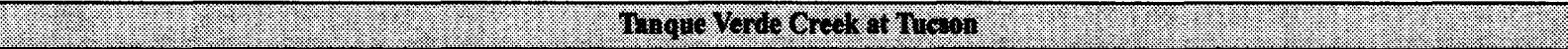 } \\
\hline 09-03-94 & $<5.0$ & $<5.0$ & $<5.0$ & $<5.0$ & $<20.0$ & $<5.0$ & $<5.0$ & $<5.0$ \\
\hline \multicolumn{9}{|c|}{ 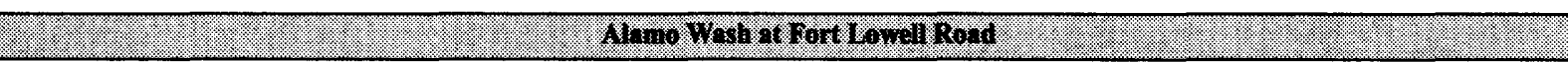 } \\
\hline $05-26-94$ & $<5.0$ & $<5.0$ & $<5.0$ & $<5.0$ & $<20.0$ & $<5.0$ & $<5.0$ & $<5.0$ \\
\hline
\end{tabular}


Table 3. Analytical results of surface-water samples, Rillito Creek basin-Continued Priority pollutants-Continued

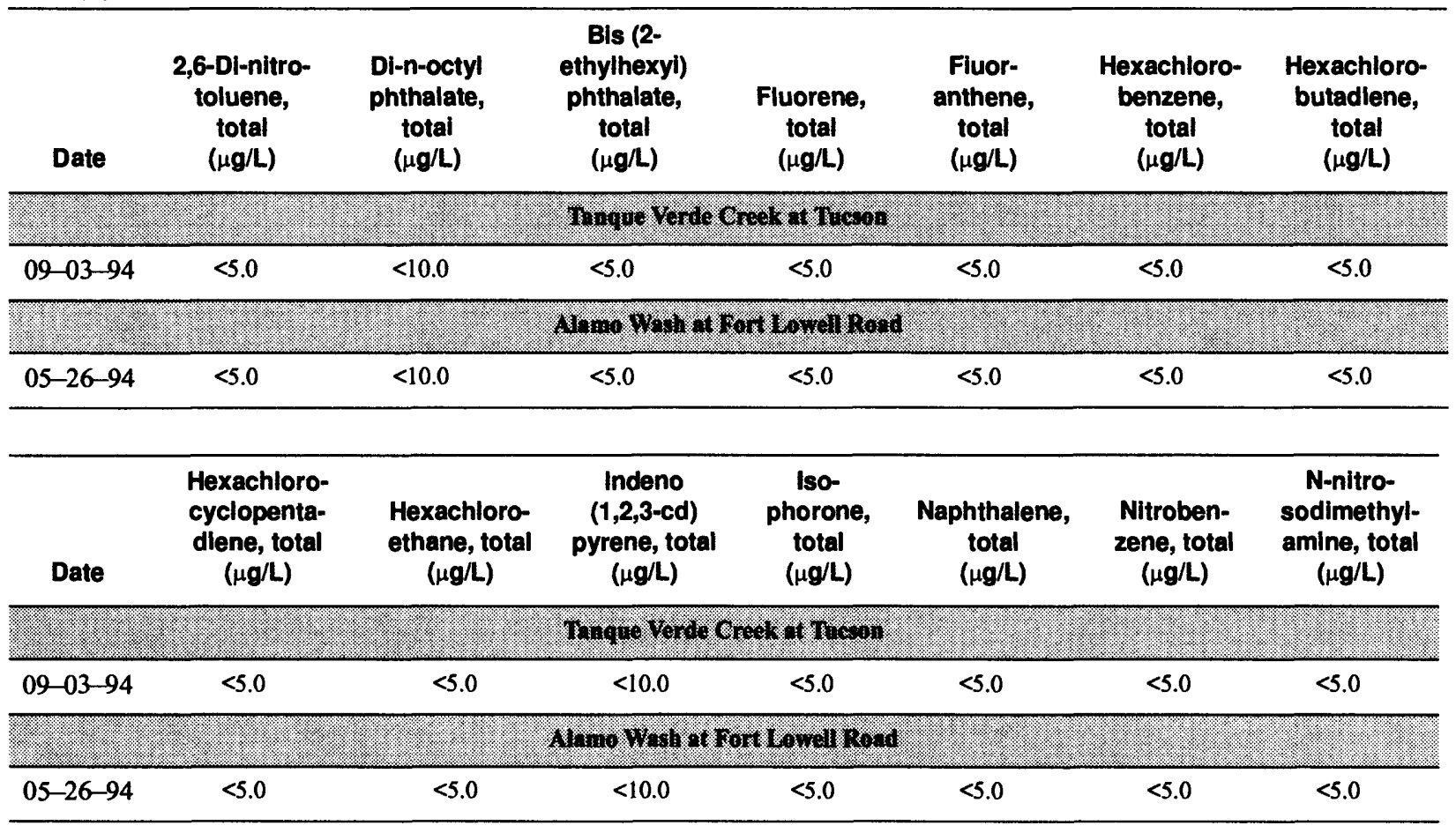

\begin{tabular}{|c|c|c|c|c|c|c|}
\hline Date & $\begin{array}{c}\text { N-nitrosodi- } \\
\text { phenylamine, } \\
\text { total } \\
(\mu \mathrm{g} / \mathrm{L})\end{array}$ & $\begin{array}{c}\text { N-nltrosodi-n- } \\
\text { propylamine, } \\
\text { total } \\
(\mu \mathrm{g} / \mathrm{L})\end{array}$ & $\begin{array}{c}\text { Phenanthrene, } \\
\text { total } \\
(\mu g / L)\end{array}$ & $\begin{array}{c}\text { Pyrene, } \\
\text { total } \\
(\mu g / L)\end{array}$ & $\begin{array}{c}1,2,4- \\
\text { Trichloro- } \\
\text { benzene, } \\
\text { total } \\
(\mu \mathrm{g} / \mathrm{L})\end{array}$ & $\begin{array}{c}\text { 1,2-Dl-phenyl- } \\
\text { hydrazine } \\
\text { total } \\
(\mu \mathrm{g} / \mathrm{L})\end{array}$ \\
\hline \multicolumn{7}{|c|}{ 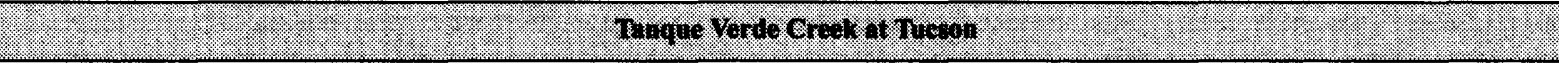 } \\
\hline $09-03-94$ & $<5.0$ & $<5.0$ & $<5.0$ & $<5.0$ & $<5.0$ & $<5.0$ \\
\hline \multicolumn{7}{|c|}{ 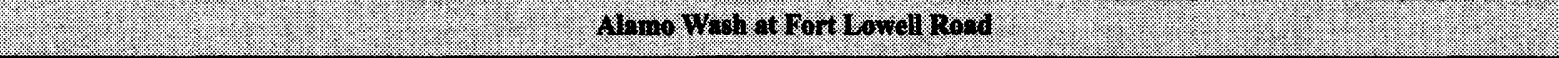 } \\
\hline $05-26-94$ & $<5.0$ & $<5.0$ & $<5.0$ & $<5.0$ & $<5.0$ & $<5.0$ \\
\hline
\end{tabular}


Table 4. Analytical results of ground-water samples, Rillito Creek basin Properties and major ions

$\left[{ }^{\circ} \mathrm{C}\right.$, degrees Celsius; $\mathrm{mm}$, millimeter; $\mu \mathrm{S} / \mathrm{cm}$, microsiemens per centimeter at $25^{\circ} \mathrm{C} ; \mathrm{mg} / \mathrm{L}$ milligrams per liter; NTU, nephelometric-turbidity units; $\mu \mathrm{g} / \mathrm{L}$, micrograms per liter; <, less than; >, greater than; $\mathrm{K}$, based on non-ideal colony count. Dashes indicate no data]

\begin{tabular}{|c|c|c|c|c|c|c|c|c|c|c|}
\hline $\begin{array}{c}\text { Well } \\
\text { Identi- } \\
\text { fication } \\
(D-13-14)\end{array}$ & Date & Time & $\begin{array}{l}\text { Water } \\
\text { levei } \\
\text { beiow } \\
\text { iand } \\
\text { surface } \\
\text { (feet) }\end{array}$ & $\begin{array}{c}\text { Water levei } \\
\text { above sea } \\
\text { ievel } \\
\text { (feet) }\end{array}$ & $\begin{array}{c}\text { Specific } \\
\text { conduct- } \\
\text { ance } \\
(\mu \mathrm{S} / \mathrm{cm})\end{array}$ & $\begin{array}{l}\text { pH } \\
\text { (stan- } \\
\text { dard } \\
\text { units) }\end{array}$ & $\begin{array}{l}\text { Temper- } \\
\text { ature, } \\
\text { water } \\
\text { ('C) }\end{array}$ & $\begin{array}{l}\text { Tur- } \\
\text { bidity } \\
\text { (NTU) }\end{array}$ & $\begin{array}{c}\text { Hard- } \\
\text { ness, } \\
\text { totai } \\
(\mathrm{mg} / \mathrm{L} \\
\text { as } \\
\left.\mathrm{CaCO}_{3}\right)\end{array}$ & $\begin{array}{c}\text { Hardness, } \\
\text { noncar- } \\
\text { bonate } \\
\text { dissoived } \\
\text { in fleld } \\
(\mathrm{mg} / \mathrm{L} \text { as } \\
\left.\mathrm{CaCO}_{3}\right)\end{array}$ \\
\hline \multirow[t]{7}{*}{$26 \mathrm{cbb} 2$} & 01-19-94 & 1040 & 41.14 & $2,368.9$ & 332 & 7.4 & 20.0 & 29 & 130 & 0 \\
\hline & $05-04-94$ & 1015 & 40.80 & $2,368.2$ & 317 & 7.0 & -- & 18 & 120 & 7 \\
\hline & $07-20-94$ & 0945 & 49.60 & $2,319.4$ & 331 & 6.8 & 20.0 & 3.4 & 130 & 0 \\
\hline & $10-07-94$ & 1000 & 50.24 & $2,358.8$ & 315 & 6.8 & 20.0 & 19 & 120 & 0 \\
\hline & 01-19-94 & 1330 & 46.93 & $2,376.1$ & 295 & 7.1 & 18.0 & 28 & 120 & 45 \\
\hline & $05-04-94$ & 1300 & 48.50 & $2,374.5$ & 263 & 6.5 & -- & 29 & 99 & 25 \\
\hline & $07-20-94$ & 1230 & 56.90 & $2,366.1$ & 244 & 6.2 & 18.0 & 150 & 100 & 19 \\
\hline $26 \mathrm{dcb} 2$ & $10-07-94$ & 1300 & 63.00 & $2,360.0$ & 231 & 6.5 & 18.0 & 210 & 92 & 4 \\
\hline
\end{tabular}

\begin{tabular}{|c|c|c|c|c|c|c|c|c|c|}
\hline $\begin{array}{c}\text { Weli } \\
\text { Identi- } \\
\text { flcatlon } \\
\text { (D-13-14) }\end{array}$ & Date & $\begin{array}{l}\text { Aikalinity, } \\
\text { water, } \\
\text { dissolved } \\
\text { In field } \\
(\mathrm{mg} / \mathrm{L} \text { as } \\
\left.\mathrm{CaCO}_{3}\right)\end{array}$ & $\begin{array}{l}\text { Solids, } \\
\text { sum of } \\
\text { con- } \\
\text { stituents, } \\
\text { dlssolved } \\
\text { (mg/L) }\end{array}$ & $\begin{array}{l}\text { Soilds, } \\
\text { residue at } \\
180^{\circ} \mathrm{C}, \\
\text { dlssolved } \\
\text { (mg/L) }\end{array}$ & $\begin{array}{l}\text { Caicium, } \\
\text { dis- } \\
\text { soived } \\
\text { (mg/L as } \\
\text { Ca) }\end{array}$ & $\begin{array}{l}\text { Magne- } \\
\text { slum, } \\
\text { dissoived } \\
\text { (mg/L } \\
\text { as Mg) }\end{array}$ & $\begin{array}{c}\text { Sodium, } \\
\text { dissoived } \\
\text { (mg/L } \\
\text { as Na) }\end{array}$ & $\begin{array}{l}\text { Sodium, } \\
\text { In } \\
\text { percent }\end{array}$ & $\begin{array}{l}\text { Sodlum- } \\
\text { adsorptlon } \\
\text { ratio }\end{array}$ \\
\hline \multirow[t]{7}{*}{$26 \mathrm{cbb} 2$} & 01-19-94 & 126 & 212 & 222 & 45 & 3.4 & 17 & 22 & 0.7 \\
\hline & $05-04-94$ & 122 & 206 & 215 & 46 & 3.4 & 16 & 21 & .6 \\
\hline & $07-20-94$ & 144 & 224 & 217 & 47 & 3.6 & 18 & 23 & .7 \\
\hline & $10-07-94$ & 130 & 202 & 208 & 43 & 3.1 & 16 & 22 & .6 \\
\hline & 01-19-94 & 74 & 171 & 201 & 41 & 3.9 & 9.9 & 15 & .4 \\
\hline & 05-04-94 & 74 & 146 & 154 & 34 & 3.3 & 8.5 & 16 & .4 \\
\hline & $07-20-94$ & 82 & 155 & 154 & 35 & 3.3 & 8.6 & 15 & .4 \\
\hline $26 \mathrm{dcb} 2$ & $10-07-94$ & 87 & 148 & 148 & 32 & 2.9 & 8.0 & 16 & .4 \\
\hline
\end{tabular}

\begin{tabular}{|c|c|c|c|c|c|c|c|c|}
\hline $\begin{array}{c}\text { Well } \\
\text { identl- } \\
\text { fication } \\
(D-13-14)\end{array}$ & Date & $\begin{array}{l}\text { Potassium, } \\
\text { dissoived } \\
\text { (mg/L as K) }\end{array}$ & $\begin{array}{c}\text { Bicar- } \\
\text { bonate, } \\
\text { dissolved } \\
\left(\mathrm{mg}^{\prime} \mathrm{L}\right. \\
\left.\text { as } \mathrm{HCO}_{3}\right)\end{array}$ & $\begin{array}{c}\text { Carbonate, } \\
\text { dissolved } \\
(\mathrm{mg} / \mathrm{L} \text { as } \\
\left.\mathrm{CO}_{3}\right)\end{array}$ & $\begin{array}{c}\text { Sulfate, } \\
\text { dissolved } \\
\left(\mathrm{mg}_{\mathrm{L}} \text { as }\right. \\
\left.\mathrm{SO}_{4}\right)\end{array}$ & $\begin{array}{c}\text { Chioride, } \\
\text { dissoived } \\
\text { (mg/L as Ci) }\end{array}$ & $\begin{array}{c}\text { Fluoride, } \\
\text { dissolved } \\
\text { (mg/L } \\
\text { as F) }\end{array}$ & $\begin{array}{c}\text { Silica, } \\
\text { dissolved } \\
(\mathbf{m g} / \mathrm{L} \\
\left.\text { as } \mathrm{SiO}_{2}\right)\end{array}$ \\
\hline \multirow[t]{7}{*}{$26 \mathrm{cbb} 2$} & $01-19-94$ & 1.4 & 154 & 0 & 23 & 4.7 & 0.10 & 34 \\
\hline & $05-04-94$ & 1.4 & 149 & 0 & 22 & 3.6 & .10 & 34 \\
\hline & $07-20-94$ & 1.0 & 176 & 0 & 23 & 3.7 & .20 & 35 \\
\hline & $10-07-94$ & 1.4 & 159 & 0 & 21 & 3.6 & .10 & 30 \\
\hline & 01-19-94 & 1.3 & 90 & 0 & 29 & 12 & .20 & 19 \\
\hline & $05-04-94$ & 1.3 & 90 & 0 & 22 & 10 & .20 & 17 \\
\hline & $07-20-94$ & 1.0 & 100 & 0 & 24 & 11 & .20 & 18 \\
\hline $26 \mathrm{dcb} 2$ & $10-07-94$ & 1.2 & 107 & 0 & 20 & 8.5 & .20 & 18 \\
\hline
\end{tabular}


Table 4. Analytical results of ground-water samples, Rillito Creek basin-Continued Nutrients, organic carbon, bacteria, and trace elements

\begin{tabular}{|c|c|c|c|c|c|c|c|c|}
\hline $\begin{array}{c}\text { Well } \\
\text { Identi- } \\
\text { flcation } \\
\text { (D-13-14) }\end{array}$ & Date & $\begin{array}{l}\text { Nitrogen, } \\
\text { nitrite, } \\
\text { dissoived } \\
\text { (mg/L } \\
\text { as } N \text { ) }\end{array}$ & $\begin{array}{l}\text { Nitrogen, } \\
\mathrm{NO}_{2}+\mathrm{NO}_{3} \text {, } \\
\text { dissolved } \\
\text { (mg/L as } \mathrm{N} \text { ) }\end{array}$ & $\begin{array}{l}\text { Nitrogen, } \\
\text { ammonia, } \\
\text { dissolved } \\
\text { (mg/L. } \\
\text { as } \mathrm{N} \text { ) }\end{array}$ & $\begin{array}{l}\text { Phos- } \\
\text { phorus } \\
\text { ortho, } \\
\text { dissolved } \\
\text { (mg/L } \\
\text { as P) }\end{array}$ & $\begin{array}{l}\text { Carbon, } \\
\text { organic, } \\
\text { dissolved } \\
\text { (mg/L } \\
\text { as C) }\end{array}$ & $\begin{array}{c}\text { Coliform, } \\
\text { fecal, } 0.7 \\
\text { UM-MF } \\
\text { (col/100 } \\
\mathrm{mL})\end{array}$ & $\begin{array}{c}\text { Strepto- } \\
\text { coccl fecal, } \\
\text { KF agar } \\
\text { (col/100 } \\
\text { mL) }\end{array}$ \\
\hline \multirow[t]{7}{*}{$26 \mathrm{cbb} 2$} & $01-19-94$ & $<0.01$ & 1.60 & 0.04 & $<.01$ & 0.9 & K10 & $>500$ \\
\hline & $05-04-94$ & $<.01$ & 1.40 & $<.01$ & $<.01$ & .7 & K5 & $>500$ \\
\hline & $07-20-94$ & $<.01$ & 1.40 & $<.01$ & $<.01$ & 1.1 & 0 & 0 \\
\hline & $10-07-94$ & $<.01$ & 1.20 & .02 & $<.01$ & 4.8 & K240 & $>500$ \\
\hline & 01-19-94 & $<.01$ & 2.20 & .07 & $<.01$ & 1.8 & 33 & 71 \\
\hline & $05-04-94$ & $<.01$ & 1.10 & .09 & $<.01$ & 2.0 & $\mathrm{~K} 2$ & $>500$ \\
\hline & $07-20-94$ & $<.01$ & .91 & .05 & $<.01$ & 2.1 & $\mathrm{~K} 180$ & 94 \\
\hline $26 \mathrm{dcb} 2$ & $10-07-94$ & .01 & .92 & .09 & $<.01$ & 2.8 & $>500$ & $>500$ \\
\hline
\end{tabular}

\begin{tabular}{|c|c|c|c|c|c|c|c|c|c|}
\hline $\begin{array}{l}\text { Well } \\
\text { Identi- } \\
\text { fication } \\
\text { (D-13-14) }\end{array}$ & Date & $\begin{array}{l}\text { Arsenic, } \\
\text { dissolved } \\
(\mu g / \mathrm{L} \text { as } \\
\text { As) }\end{array}$ & $\begin{array}{l}\text { Barlum, } \\
\text { dissolved } \\
(\mu \mathrm{g} / \mathrm{L} \text { as } \\
\mathrm{Ba})\end{array}$ & $\begin{array}{c}\text { Boron, } \\
\text { dissolved } \\
(\mu g / L \text { as B) }\end{array}$ & $\begin{array}{l}\text { Cadmium, } \\
\text { dissolved } \\
\text { ( } \mu \text { g/L } \\
\text { as Cd) }\end{array}$ & $\begin{array}{c}\text { Chromium, } \\
\text { dissolved } \\
(\mu \mathrm{g} / \mathrm{L} \\
\text { as Cr) }\end{array}$ & $\begin{array}{c}\text { Copper, } \\
\text { dissolved } \\
(\mu \mathrm{g} / \mathrm{L} \\
\text { as Cu) }\end{array}$ & $\begin{array}{l}\text { Iron, dis- } \\
\text { soived } \\
(\mu \mathrm{g} / \mathrm{L} \\
\text { as Fe) }\end{array}$ & $\begin{array}{c}\text { Lead, } \\
\text { dis- } \\
\text { solved } \\
(\mu g / L \\
\text { as } \mathrm{Pb})\end{array}$ \\
\hline \multirow[t]{7}{*}{$26 \mathrm{cbb} 2$} & $01-19-94$ & 2 & 5 & 30 & $<1.0$ & $<1$ & 60 & 13 & $<1$ \\
\hline & $05-04-94$ & $<1$ & 7 & 30 & $<1.0$ & $<1$ & $<10$ & 19 & $<1$ \\
\hline & $07-20-94$ & $<1$ & 7 & 20 & $<1.0$ & $<1$ & $<10$ & 34 & $<1$ \\
\hline & $10-07-94$ & $<1$ & 6 & 30 & $<1.0$ & $<1$ & $<10$ & 26 & $<1$ \\
\hline & 01-19-94 & $<1$ & 37 & 20 & $<1.0$ & $<1$ & $<10$ & 80 & $<1$ \\
\hline & $05-04-94$ & $<1$ & 54 & 40 & $<1.0$ & $<1$ & $<10$ & 13 & $<1$ \\
\hline & $07-20-94$ & $<1$ & 42 & 10 & $<1.0$ & $<1$ & $<10$ & 36 & $<1$ \\
\hline $26 \mathrm{dcb} 2$ & $10-07-94$ & $<1$ & 50 & 10 & $<1.0$ & $<1$ & $<10$ & 14 & $<1$ \\
\hline
\end{tabular}

\begin{tabular}{|c|c|c|c|c|c|c|c|c|c|}
\hline $\begin{array}{c}\text { Well } \\
\text { Identi- } \\
\text { fication } \\
(\mathrm{D}-13-14)\end{array}$ & Date & $\begin{array}{c}\text { Manga- } \\
\text { nese, } \\
\text { dissolved } \\
(\mu \mathrm{g} / \mathrm{L} \\
\text { as Mn) }\end{array}$ & $\begin{array}{c}\text { Mercury, } \\
\text { dissolved } \\
(\mu \mathrm{g} / \mathrm{L} \\
\text { as } \mathrm{Hg})\end{array}$ & $\begin{array}{c}\text { Molybde- } \\
\text { num, } \\
\text { dissolved } \\
(\mu \mathrm{g} / \mathrm{L} \\
\text { as Mo) }\end{array}$ & $\begin{array}{c}\text { Nickel, } \\
\text { dissolved } \\
(\mu \mathrm{g} / \mathrm{L} \\
\text { as NI) }\end{array}$ & $\begin{array}{c}\text { Selenium, } \\
\text { dissolved } \\
\text { ( } \mu \mathrm{g} / \mathrm{L} \\
\text { as Se) }\end{array}$ & $\begin{array}{c}\text { Silver, } \\
\text { dissolved } \\
(\mu \mathrm{g} / \mathrm{L} \\
\text { as } \mathrm{Ag})\end{array}$ & $\begin{array}{c}\text { Vanadium, } \\
\text { dissolved } \\
(\mu \mathrm{g} / \mathrm{L} \\
\text { as V) }\end{array}$ & $\begin{array}{l}\text { Zinc, } \\
\text { dis- } \\
\text { solved } \\
(\mu g / L \\
\text { as Zn) }\end{array}$ \\
\hline \multirow[t]{7}{*}{$26 \mathrm{cbb} 2$} & $01-19-94$ & 81 & $<.1$ & $<1$ & 3 & $<1$ & $<1.0$ & 2 & 6 \\
\hline & $05-04-94$ & 60 & $<.1$ & $<1$ & $<1$ & $<1$ & $<1.0$ & 2 & 4 \\
\hline & $07-20-94$ & 91 & $<.1$ & $<1$ & $<1$ & $<1$ & $<1.0$ & 2 & 11 \\
\hline & $10-07-94$ & 110 & $<.1$ & $<1$ & $<1$ & $<1$ & $<1.0$ & 1 & 35 \\
\hline & $01-19-94$ & 110 & $<.1$ & $<1$ & 2 & $<1$ & $<1.0$ & $<1$ & 12 \\
\hline & $05-04-94$ & 180 & $<.1$ & $<1$ & $<1$ & $<1$ & $<1.0$ & $<1$ & 21 \\
\hline & $07-20-94$ & 230 & .1 & $<1$ & $<1$ & $<1$ & $<1.0$ & $<1$ & 5 \\
\hline $26 \mathrm{dcb} 2$ & $10-07-94$ & 180 & $<.1$ & $<1$ & $<1$ & $<1$ & $<1.0$ & $<1$ & 7 \\
\hline
\end{tabular}


Table 4. Analytical results of ground-water samples, Rillito Creek basin-Continued Organochlorine pesticides

[DDD, dichlorodiphenyldichloroethane; DDE, dichlorodiphenylethylene; DDT, dichlorodiphenyltrichloroethane]

\begin{tabular}{|c|c|c|c|c|c|c|c|c|c|}
\hline $\begin{array}{c}\text { Well } \\
\text { identl- } \\
\text { ficatlon } \\
\text { (D-13-14) }\end{array}$ & Date & $\begin{array}{c}\text { Perthane, } \\
\text { total } \\
(\mu g / L)\end{array}$ & $\begin{array}{c}\text { Endosulfate, } \\
\text { totai } \\
(\mu g / L)\end{array}$ & $\begin{array}{l}\text { Aldrin, } \\
\text { total } \\
(\mu g / L)\end{array}$ & $\begin{array}{c}\text { Chlordane, } \\
\text { total } \\
(\mu \mathrm{g} / \mathrm{L})\end{array}$ & $\begin{array}{l}\text { DDD, } \\
\text { total } \\
(\mu g / L)\end{array}$ & $\begin{array}{l}\text { DDE, } \\
\text { total } \\
(\mu g / L)\end{array}$ & $\begin{array}{l}\text { DDT, } \\
\text { totai } \\
(\mu g / L)\end{array}$ & $\begin{array}{c}\text { Dieldrin, } \\
\text { total } \\
(\mu \mathrm{g} / \mathrm{L})\end{array}$ \\
\hline \multirow[t]{7}{*}{$26 \mathrm{cbb} 2$} & 01-19-94 & $<0.1$ & $<0.010$ & $<0.010$ & $<0.1$ & $<0.010$ & $<0.010$ & $<0.010$ & $<0.010$ \\
\hline & $05-04-94$ & $<.1$ & $<.010$ & $<.010$ & $<.1$ & $<.010$ & $<.010$ & $<.010$ & $<.010$ \\
\hline & $07-20-94$ & $<.1$ & $<.010$ & $<.010$ & $<.1$ & $<.010$ & $<.010$ & $<.010$ & $<.010$ \\
\hline & $10-07-94$ & $<.1$ & $<.010$ & $<.010$ & $<.1$ & $<.010$ & $<.010$ & $<.010$ & $<.010$ \\
\hline & $01-19-94$ & $<.1$ & $<.010$ & $<.010$ & $<.1$ & $<.010$ & $<.010$ & $<.010$ & $<.010$ \\
\hline & $05-04-94$ & $<.1$ & $<.010$ & $<.010$ & $<.1$ & $<.010$ & $<.010$ & $<.010$ & $<.010$ \\
\hline & $07-20-94$ & $<.1$ & $<.010$ & $<.010$ & $<.1$ & $<.010$ & $<.010$ & $<.010$ & $<.010$ \\
\hline $26 \mathrm{dcb} 2$ & $10-07-94$ & $<.1$ & $<.010$ & $\cdots$ & $<.1$ & $<.010$ & $<.010$ & $<.010$ & $<.010$ \\
\hline
\end{tabular}

\begin{tabular}{|c|c|c|c|c|c|c|c|c|c|c|}
\hline $\begin{array}{c}\text { Weil } \\
\text { Identi- } \\
\text { ficatlon } \\
\text { (D-13-14) }\end{array}$ & Date & $\begin{array}{c}\text { Endrin, } \\
\text { total } \\
(\mu g / L)\end{array}$ & $\begin{array}{l}\text { Hepta- } \\
\text { chlor, } \\
\text { total } \\
(\mu g / L)\end{array}$ & $\begin{array}{l}\text { Hepta- } \\
\text { chior } \\
\text { epoxide, } \\
\text { total } \\
(\mu g / L)\end{array}$ & $\begin{array}{c}\text { Lindane, } \\
\text { total } \\
(\mu g / L)\end{array}$ & $\begin{array}{c}\text { Toxa- } \\
\text { phene, } \\
\text { total } \\
(\mu \mathrm{g} / \mathrm{L})\end{array}$ & $\begin{array}{c}\text { Biphenyl, } \\
\text { poly- } \\
\text { chlor, } \\
\text { total } \\
(\mu g / L)\end{array}$ & $\begin{array}{c}\text { Naph- } \\
\text { thalene, } \\
\text { poly- } \\
\text { chlor } \\
\text { total } \\
(\mu g / L)\end{array}$ & $\begin{array}{l}\text { Meth- } \\
\text { oxy- } \\
\text { chlor, } \\
\text { total } \\
(\mu g / L)\end{array}$ & $\begin{array}{c}\text { Mirex } \\
\text { total } \\
(\mu g / L)\end{array}$ \\
\hline \multirow[t]{7}{*}{$26 \mathrm{cbb} 2$} & 01-19-94 & $<0.010$ & $<0.010$ & $<0.010$ & $<0.010$ & $<1$ & $<0.1$ & $<0.01$ & $<0.01$ & $<0.01$ \\
\hline & $05-04-94$ & $<.010$ & $<.010$ & $<.010$ & $<.010$ & $<1$ & $<.1$ & $<.01$ & $<.01$ & $<.01$ \\
\hline & $07-20-94$ & $<.010$ & $<.010$ & $<.010$ & $<.010$ & $<1$ & $<.1$ & $<.01$ & $<.01$ & $<.01$ \\
\hline & $10-07-94$ & $<.010$ & $<.010$ & $<.010$ & $<.010$ & $<1$ & $<.1$ & $<.01$ & $<.01$ & $<.01$ \\
\hline & 01-19-94 & $<.010$ & $<.010$ & $<.010$ & $<.010$ & $<1$ & $<.1$ & $<.01$ & $<.01$ & $<.01$ \\
\hline & $05-04-94$ & $<.010$ & $<.010$ & $<.010$ & $<.010$ & $<1$ & $<.1$ & $<.01$ & $<.01$ & $<.01$ \\
\hline & $07-20-94$ & $<.010$ & $<.010$ & $<.010$ & $<.010$ & $<1$ & $<.1$ & $<.01$ & $<.01$ & $<.01$ \\
\hline $26 \mathrm{dcb} 2$ & $10-07-94$ & $<.010$ & -.. & $<.010$ & -- & $<1$ & $<.1$ & $<.01$ & $<.01$ & $<.01$ \\
\hline
\end{tabular}

Priority pollutants

\begin{tabular}{|c|c|c|c|c|c|c|c|c|c|}
\hline $\begin{array}{c}\text { Well } \\
\text { identi- } \\
\text { flcation } \\
\text { (D-13-14) }\end{array}$ & Date & $\begin{array}{c}\text { Para- } \\
\text { chloro- } \\
\text { meta } \\
\text { cresol, } \\
\text { total } \\
(\mu \mathrm{g} / \mathrm{L})\end{array}$ & $\begin{array}{c}\text { 2- } \\
\text { Chloro- } \\
\text { phenol, } \\
\text { total } \\
(\mu g / L)\end{array}$ & $\begin{array}{c}\text { 2,4-Di- } \\
\text { chloro- } \\
\text { phenol, } \\
\text { total } \\
(\mu \mathrm{g} / \mathrm{L})\end{array}$ & $\begin{array}{c}2,4,6-T r i- \\
\text { chioro- } \\
\text { phenol, } \\
\text { total } \\
(\mu g / L)\end{array}$ & $\begin{array}{c}\text { 2,4-Dl- } \\
\text { methyl- } \\
\text { phenol, } \\
\text { total } \\
(\mu \mathrm{g} / \mathrm{L})\end{array}$ & $\begin{array}{c}\text { 4,6-Dl- } \\
\text { nltro- } \\
\text { ortho- } \\
\text { cresol, } \\
\text { total } \\
(\mu \mathrm{g} / \mathrm{L})\end{array}$ & $\begin{array}{c}\text { 2,4-Di- } \\
\text { nltro- } \\
\text { phenol, } \\
\text { total } \\
(\mu \mathrm{g} / \mathrm{L})\end{array}$ & $\begin{array}{c}\text { 2-Nitro- } \\
\text { phenol, } \\
\text { total } \\
(\mu \mathrm{g} / \mathrm{L})\end{array}$ \\
\hline \multirow[t]{7}{*}{$26 \mathrm{cbb} 2$} & 01-19-94 & -- & --- & -- & -- & -- & -- & -- & -- \\
\hline & $05-04-94$ & $<30.0$ & $<5.0$ & $<5.0$ & $<20.0$ & $<5.0$ & $<30.0$ & $<20.0$ & $<5.0$ \\
\hline & $07-20-94$ & $<30.0$ & $<5.0$ & $<5.0$ & $<20.0$ & $<5.0$ & $<30.0$ & $<20.0$ & $<5.0$ \\
\hline & $10-07-94$ & & $<5.0$ & $<5.0$ & $<20.0$ & $<5.0$ & $<30.0$ & $<20.0$ & $<5.0$ \\
\hline & $01-19-94$ & $<30.0$ & $<5.0$ & $<5.0$ & $<20.0$ & $<5.0$ & $<30.0$ & $<20.0$ & $<5.0$ \\
\hline & 05-04-94 & $<30.0$ & $<5.0$ & $<5.0$ & $<20.0$ & $<5.0$ & $<30.0$ & $<20.0$ & $<5.0$ \\
\hline & $07-20-94$ & $<30.0$ & $<5.0$ & $<5.0$ & $<20.0$ & $<5.0$ & $<30.0$ & $<20.0$ & $<5.0$ \\
\hline $26 \mathrm{dcb} 2$ & $10-07-94$ & $<30.0$ & $<5.0$ & $<5.0$ & $<20.0$ & $<5.0$ & $<30.0$ & $<20.0$ & $<5.0$ \\
\hline
\end{tabular}


Table 4. Analytical results of ground-water samples, Rillito Creek basin-Continued Priority pollutants-Continued

\begin{tabular}{|c|c|c|c|c|c|c|c|c|c|}
\hline $\begin{array}{c}\text { Well } \\
\text { identi- } \\
\text { fication } \\
(D-13-14)\end{array}$ & Date & $\begin{array}{c}\text { 4-Nitro- } \\
\text { phenoi, } \\
\text { totai } \\
(\mu \mathrm{g} / \mathrm{L})\end{array}$ & $\begin{array}{c}\text { Penta- } \\
\text { chioro- } \\
\text { phenol, } \\
\text { totai } \\
(\mu \mathrm{g} / \mathrm{L})\end{array}$ & $\begin{array}{c}\text { Phenol, } \\
\text { (C6h-50h) } \\
\text { totai } \\
(\mu g / L)\end{array}$ & $\begin{array}{l}\text { Ace- } \\
\text { naph- } \\
\text { thene, } \\
\text { totai } \\
(\mu g / L)\end{array}$ & $\begin{array}{c}\text { Ace- } \\
\text { naph- } \\
\text { thyiene, } \\
\text { totai } \\
(\mu g / L)\end{array}$ & $\begin{array}{l}\text { Anthra- } \\
\text { cene, } \\
\text { totai } \\
(\mu g / L)\end{array}$ & $\begin{array}{c}\text { Benzidine, } \\
\text { totai } \\
(\mu \mathrm{g} / \mathrm{L})\end{array}$ & $\begin{array}{c}\text { Benzo-(a)- } \\
\text { anthracene } \\
\text { 1,2-benzan- } \\
\text { thracene, } \\
\text { totai } \\
(\mu \mathrm{g} / \mathrm{L})\end{array}$ \\
\hline \multirow[t]{7}{*}{$26 \mathrm{cbb} 2$} & $01-19-94$ & -- & -- & $\cdots$ & -- & $\cdots$ & -- & -- & - \\
\hline & $05-04-94$ & $<30.0$ & $<30.0$ & $<5.0$ & $<5.0$ & $<5.0$ & $<5.0$ & $<40.0$ & $<100$ \\
\hline & $07-20-94$ & $<30.0$ & $<30.0$ & $<5.0$ & $<5.0$ & $<5.0$ & $<5.0$ & $<40.0$ & $\begin{array}{l}<10.0 \\
<100\end{array}$ \\
\hline & $10-07-94$ & $<30.0$ & $<30.0$ & $<5.0$ & $<5.0$ & $<5.0$ & $<5.0$ & $<40.0$ & $<10.0$ \\
\hline & $01-19-94$ & $<30.0$ & $<30.0$ & $<5.0$ & $<5.0$ & $<5.0$ & $<5.0$ & $<40.0$ & $<10.0$ \\
\hline & 05-04-94 & $<30.0$ & $<30.0$ & $<5.0$ & $<5.0$ & $<5.0$ & $<5.0$ & $<40.0$ & $<10.0$ \\
\hline & $07-20-94$ & $<30.0$ & $<30.0$ & $<5.0$ & $<5.0$ & $<5.0$ & $<5.0$ & $<40.0$ & $<10.0$ \\
\hline $26 \mathrm{dcb} 2$ & $10-07-94$ & $<30.0$ & $<30.0$ & $<5.0$ & $<5.0$ & $<5.0$ & $<5.0$ & $<40.0$ & $<10.0$ \\
\hline
\end{tabular}

\begin{tabular}{|c|c|c|c|c|c|c|c|c|c|}
\hline $\begin{array}{c}\text { Weli } \\
\text { Identi- } \\
\text { fication } \\
\text { (D-13-14) }\end{array}$ & Date & $\begin{array}{l}\text { Benzo- } \\
\text { (b)- } \\
\text { fluor- } \\
\text { anthene, } \\
\text { totai } \\
(\mu \mathrm{g} / \mathrm{L})\end{array}$ & $\begin{array}{l}\text { Benzo- } \\
\text { (k)- } \\
\text { fluor- } \\
\text { anthene, } \\
\text { totai } \\
(\mu \mathrm{g} / \mathrm{L})\end{array}$ & $\begin{array}{c}\text { Benzo- } \\
\text { (a)- } \\
\text { pyrene, } \\
\text { total } \\
(\mu g / L)\end{array}$ & $\begin{array}{c}\text { Benzogh(i)i } \\
\text { peryiene,1, } \\
\text { 12-benzo- } \\
\text { peryiene, } \\
\text { total } \\
(\mu \mathrm{g} / \mathrm{L})\end{array}$ & $\begin{array}{l}\text { N-butyi- } \\
\text { benziy- } \\
\text { phthai } \\
\text { ate, } \\
\text { total } \\
(\mu g / L)\end{array}$ & $\begin{array}{l}\text { Bis (2- } \\
\text { chioro- } \\
\text { ethoxy) } \\
\text { methane, } \\
\text { total } \\
(\mu \mathrm{g} / \mathrm{L})\end{array}$ & $\begin{array}{l}\text { Bis (2- } \\
\text { chioro- } \\
\text { ethyi) } \\
\text { ether, } \\
\text { totai } \\
(\mu g / L)\end{array}$ & $\begin{array}{c}\text { Bis (2- } \\
\text { chioro- } \\
\text { iso- } \\
\text { propyi) } \\
\text { ether, } \\
\text { totai } \\
(\mu \mathrm{g} / \mathrm{L})\end{array}$ \\
\hline \multirow[t]{7}{*}{$26 \mathrm{cbb} 2$} & 01-19-94 & -+ & $\cdots$ & -.- & -- & -- & $\ldots$ & -- & $\cdots$ \\
\hline & $05-04-94$ & $<10.0$ & $<10.0$ & $<10.0$ & $<10.0$ & $<5.0$ & $<5.0$ & $<5.0$ & $<5.0$ \\
\hline & $07-20-94$ & $<10.0$ & $<10.0$ & $<10.0$ & $<10.0$ & $<5.0$ & $<5.0$ & $<5.0$ & $<5.0$ \\
\hline & $10-07-94$ & $<10.0$ & $<10.0$ & $<10.0$ & $<10.0$ & $<5.0$ & $<5.0$ & $<5.0$ & $<5.0$ \\
\hline & $01-19-94$ & $<10.0$ & $<10.0$ & $<10.0$ & $<10.0$ & $<5.0$ & $<5.0$ & $<5.0$ & $<5.0$ \\
\hline & $05-04-94$ & $<10.0$ & $<10.0$ & $<10.0$ & $<10.0$ & $<5.0$ & $<5.0$ & $<5.0$ & $<5.0$ \\
\hline & $07-20-94$ & $<10.0$ & $<10.0$ & $<10.0$ & $<10.0$ & $<5.0$ & $<5.0$ & $<5.0$ & $<5.0$ \\
\hline $26 \mathrm{dcb} 2$ & $10-07-94$ & $<10.0$ & $<10.0$ & $<10.0$ & $<10.0$ & $<5.0$ & $<5.0$ & $<5.0$ & $<5.0$ \\
\hline
\end{tabular}

\begin{tabular}{|c|c|c|c|c|c|c|c|c|c|}
\hline $\begin{array}{c}\text { Weil } \\
\text { identi- } \\
\text { fication } \\
\text { (D-13-14) }\end{array}$ & Date & $\begin{array}{c}4- \\
\text { Bromo- } \\
\text { phenyi } \\
\text { phenyi } \\
\text { ether, } \\
\text { totai } \\
(\mu \mathrm{g} / \mathrm{L})\end{array}$ & $\begin{array}{c}2- \\
\text { Chioro- } \\
\text { naph- } \\
\text { tha- } \\
\text { lene, } \\
\text { totai } \\
\text { ( } \mu \mathrm{g} / \mathrm{L})\end{array}$ & $\begin{array}{c}\text { 4- } \\
\text { Chioro- } \\
\text { phenyi } \\
\text { phenyi } \\
\text { ether, } \\
\text { totai } \\
(\mu g / L)\end{array}$ & $\begin{array}{l}\text { Chry- } \\
\text { sene, } \\
\text { totai } \\
(\mu g / L)\end{array}$ & $\begin{array}{c}\text { 1,2,5,6 } \\
\text { Dibenz- } \\
\text { anthra- } \\
\text { cene, } \\
\text { totai } \\
(\mu \mathrm{g} / \mathrm{L})\end{array}$ & $\begin{array}{c}\text { Di-n- } \\
\text { butyi } \\
\text { phthal- } \\
\text { ate, } \\
\text { totai } \\
(\mu \mathrm{g} / \mathrm{L})\end{array}$ & $\begin{array}{c}\text { 1,2- } \\
\text { Chioro- } \\
\text { benzene, } \\
\text { totai } \\
(\mu \mathrm{g} / \mathrm{L})\end{array}$ & $\begin{array}{c}\text { 1,3-Di- } \\
\text { chioro- } \\
\text { benzene, } \\
\text { totai } \\
(\mu \mathrm{g} / \mathrm{L})\end{array}$ \\
\hline \multirow[t]{7}{*}{$26 \mathrm{cbb} 2$} & 01-19-94 & $\cdots$ & -- & -- & --- & -- & 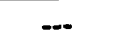 & -- & -- \\
\hline & $05-04-94$ & $<5.0$ & $<5.0$ & $<5.0$ & $<10.0$ & $<10.0$ & $<5.0$ & $<5.0$ & $<5.0$ \\
\hline & $07-20-94$ & $<5.0$ & $<5.0$ & $<5.0$ & $<10.0$ & $<10.0$ & $<5.0$ & $<5.0$ & $<5.0$ \\
\hline & $10-07-94$ & $<5.0$ & $<5.0$ & $<5.0$ & $<10.0$ & $<10.0$ & $<5.0$ & $<5.0$ & $<5.0$ \\
\hline & 01-19-94 & $<5.0$ & $<5.0$ & $<5.0$ & $<10.0$ & $<10.0$ & $<5.0$ & $<5.0$ & $<5.0$ \\
\hline & $05-04-94$ & $<5.0$ & $<5.0$ & $<5.0$ & $<10.0$ & $<10.0$ & $<5.0$ & $<5.0$ & $<5.0$ \\
\hline & $07-20-94$ & $<5.0$ & $<5.0$ & $<5.0$ & $<10.0$ & $<10.0$ & $<5.0$ & $<5.0$ & $<5.0$ \\
\hline 26dcb2 & $10-07-94$ & $<5.0$ & $<5.0$ & $<5.0$ & $<10.0$ & $<10.0$ & $<5.0$ & $<5.0$ & $<5.0$ \\
\hline
\end{tabular}


Table 4. Analytical results of ground-water samples, Rillito Creek basin-Continued Priority pollutants-Continued

\begin{tabular}{|c|c|c|c|c|c|c|c|c|c|}
\hline $\begin{array}{c}\text { Weil } \\
\text { identi- } \\
\text { fication } \\
(D-13-14)\end{array}$ & Date & $\begin{array}{c}\text { 1,4-DI- } \\
\text { chioro- } \\
\text { benzene, } \\
\text { totai } \\
(\mu g / L)\end{array}$ & $\begin{array}{c}\text { 3,3-Di- } \\
\text { chioro- } \\
\text { benzi- } \\
\text { dine, } \\
\text { totai } \\
(\mu \mathrm{g} / \mathrm{L})\end{array}$ & $\begin{array}{c}\text { Dl- } \\
\text { ethyl } \\
\text { phthai- } \\
\text { ate, } \\
\text { totai } \\
(\mu g / L)\end{array}$ & $\begin{array}{c}\text { Di- } \\
\text { methyl- } \\
\text { phthai- } \\
\text { ate, } \\
\text { totai } \\
(\mu g / L)\end{array}$ & $\begin{array}{c}\text { 2,4-Di- } \\
\text { nitro- } \\
\text { toluene, } \\
\text { totai } \\
(\mu g / L)\end{array}$ & $\begin{array}{c}\text { 2,6-Di- } \\
\text { nltro- } \\
\text { toluene, } \\
\text { total } \\
(\mu g / L)\end{array}$ & $\begin{array}{c}\text { Dl-n- } \\
\text { octyl } \\
\text { phthal- } \\
\text { ate, } \\
\text { total } \\
(\mu g / L)\end{array}$ & $\begin{array}{c}\text { Bis (2- } \\
\text { ethyi- } \\
\text { hexyl) } \\
\text { phthai- } \\
\text { ate, } \\
\text { totai } \\
(\mu g / L)\end{array}$ \\
\hline \multirow[t]{7}{*}{$26 \mathrm{cbb} 2$} & $01-19-94$ & -- & --- & -- & -- & --- & --- & --- & --- \\
\hline & $05-04-94$ & $<5.0$ & $<20.0$ & $<5.0$ & $<5.0$ & $<5.0$ & $<5.0$ & $<10.0$ & $<5.0$ \\
\hline & $07-20-94$ & $<5.0$ & $<20.0$ & $<5.0$ & $<5.0$ & $<5.0$ & $<5.0$ & $<10.0$ & $<5.0$ \\
\hline & $10-07-94$ & $<5.0$ & $<20.0$ & $<5.0$ & $<5.0$ & $<5.0$ & $<5.0$ & $<10.0$ & $<5.0$ \\
\hline & 01-19-94 & $<5.0$ & $<20.0$ & $<5.0$ & $<5.0$ & $<5.0$ & $<5.0$ & $<10.0$ & $<5.0$ \\
\hline & $05-04-94$ & $<5.0$ & $<20.0$ & $<5.0$ & $<5.0$ & $<5.0$ & $<5.0$ & $<10.0$ & $<5.0$ \\
\hline & $07-20-94$ & $<5.0$ & $<20.0$ & $<5.0$ & $<5.0$ & $<5.0$ & $<5.0$ & $<10.0$ & $<5.0$ \\
\hline $26 \mathrm{dcb} 2$ & $10-07-94$ & $<5.0$ & $<20.0$ & $<5.0$ & $<5.0$ & $<5.0$ & $<5.0$ & $<10.0$ & $<5.0$ \\
\hline
\end{tabular}

\begin{tabular}{|c|c|c|c|c|c|c|c|c|c|}
\hline $\begin{array}{c}\text { Well } \\
\text { identi- } \\
\text { fication } \\
\text { (D-13-14) }\end{array}$ & Date & $\begin{array}{c}\text { Fiuorene, } \\
\text { total } \\
(\mu g / L)\end{array}$ & $\begin{array}{c}\text { Fiuor- } \\
\text { anthene, } \\
\text { totai } \\
(\mu \mathrm{g} / \mathrm{L})\end{array}$ & $\begin{array}{c}\text { Hexachloro- } \\
\text { benzene, } \\
\text { total } \\
(\mu \mathrm{g} / \mathrm{L})\end{array}$ & $\begin{array}{l}\text { Hexa- } \\
\text { chioro- } \\
\text { buta- } \\
\text { diene, } \\
\text { totai } \\
(\mu g / L)\end{array}$ & $\begin{array}{c}\text { Hexa- } \\
\text { chioro- } \\
\text { cyclo- } \\
\text { penta- } \\
\text { diene, } \\
\text { total } \\
(\mu \mathrm{g} / \mathrm{L})\end{array}$ & $\begin{array}{c}\text { Hexa- } \\
\text { chioro- } \\
\text { ethane, } \\
\text { totai } \\
(\mu g / L)\end{array}$ & $\begin{array}{c}\text { Indeno } \\
(1,2,3-c d) \\
\text { pyrene, } \\
\text { totai } \\
(\mu g / L)\end{array}$ & $\begin{array}{l}\text { Iso- } \\
\text { phor- } \\
\text { one, } \\
\text { totai } \\
(\mu \mathrm{g} / \mathrm{L})\end{array}$ \\
\hline \multirow[t]{7}{*}{$26 \mathrm{cbb} 2$} & $01-19-94$ & $\cdots$ & --- & -- & -- & -- & --- & --- & - \\
\hline & $05-04-94$ & $<5.0$ & $<5.0$ & $<5.0$ & $<5.0$ & $<5.0$ & $<5.0$ & $<10.0$ & $<5.0$ \\
\hline & $07-20-94$ & $<5.0$ & $<5.0$ & $<5.0$ & $<5.0$ & $<5.0$ & $<5.0$ & $<10.0$ & $<5.0$ \\
\hline & $10-07-94$ & $<5.0$ & $<5.0$ & $<5.0$ & $<5.0$ & $<5.0$ & $<5.0$ & $<10.0$ & $<5.0$ \\
\hline & $01-19-94$ & $<5.0$ & $<5.0$ & $<5.0$ & $<5.0$ & $<5.0$ & $<5.0$ & $<10.0$ & $<5.0$ \\
\hline & $05-04-94$ & $<5.0$ & $<5.0$ & $<5.0$ & $<5.0$ & $<5.0$ & $<5.0$ & $<10.0$ & $<5.0$ \\
\hline & $07-20-94$ & $<5.0$ & $<5.0$ & $<5.0$ & $<5.0$ & $<5.0$ & $<5.0$ & $<10.0$ & $<5.0$ \\
\hline $26 \mathrm{dcb} 2$ & $10-07-94$ & $<5.0$ & $<5.0$ & $<5.0$ & $<5.0$ & $<5.0$ & $<5.0$ & $<10.0$ & $<5.0$ \\
\hline
\end{tabular}

\begin{tabular}{|c|c|c|c|c|c|c|c|c|c|c|}
\hline $\begin{array}{c}\text { Well } \\
\text { Identl- } \\
\text { fication } \\
\text { (D-13-14) }\end{array}$ & Date & $\begin{array}{c}\text { Naph- } \\
\text { thaiene, } \\
\text { total } \\
(\mu \mathrm{g} / \mathrm{L})\end{array}$ & $\begin{array}{l}\text { Nitro- } \\
\text { ben- } \\
\text { zene, } \\
\text { total } \\
(\mu \mathrm{g} / \mathrm{L})\end{array}$ & $\begin{array}{l}\text { N-nitro- } \\
\text { sodi- } \\
\text { methyl- } \\
\text { amine, } \\
\text { totai } \\
(\mu \mathrm{g} / \mathrm{L})\end{array}$ & $\begin{array}{l}\text { N-nitro- } \\
\text { sodl- } \\
\text { phenyl- } \\
\text { amine, } \\
\text { total } \\
(\mu g / L)\end{array}$ & $\begin{array}{c}\text { N-nitro- } \\
\text { sodi-n- } \\
\text { propyl- } \\
\text { amine, } \\
\text { totai } \\
(\mu \mathrm{g} / \mathrm{L})\end{array}$ & $\begin{array}{l}\text { Phen- } \\
\text { anth- } \\
\text { rene, } \\
\text { total } \\
(\mu g / L)\end{array}$ & $\begin{array}{c}\text { Pyrene, } \\
\text { total } \\
(\mu g / L)\end{array}$ & $\begin{array}{c}\text { 1,2,4- } \\
\text { Trl- } \\
\text { chloro- } \\
\text { benzene, } \\
\text { total } \\
(\mu \mathrm{g} / \mathrm{L})\end{array}$ & $\begin{array}{c}\text { 1,2-Dl- } \\
\text { phenyl- } \\
\text { hydra- } \\
\text { zine, } \\
\text { total } \\
(\mu g / L)\end{array}$ \\
\hline \multirow[t]{7}{*}{$26 \mathrm{cbb} 2$} & $01-19-94$ & -- & $\cdots$ & $\ldots$ & $\cdots$ & -- & -- & -- & --- & -- \\
\hline & $05-04-94$ & $<5.0$ & $<5.0$ & $<5.0$ & $<5.0$ & $<5.0$ & $<5.0$ & $<5.0$ & $<5.0$ & $<5.0$ \\
\hline & $07-20-94$ & $<5.0$ & $<5.0$ & $<5.0$ & $<5.0$ & $<5.0$ & $<5.0$ & $<5.0$ & $<5.0$ & $<5.0$ \\
\hline & $10-07-94$ & $<5.0$ & $<5.0$ & $<5.0$ & $<5.0$ & $<5.0$ & $<5.0$ & $<5.0$ & $<5.0$ & $<5.0$ \\
\hline & $01-19-94$ & $<5.0$ & $<5.0$ & $<5.0$ & $<5.0$ & $<5.0$ & $<5.0$ & $<5.0$ & $<5.0$ & $<5.0$ \\
\hline & $05-04-94$ & $<5.0$ & $<5.0$ & $<5.0$ & $<5.0$ & $<5.0$ & $<5.0$ & $<5.0$ & $<5.0$ & $<5.0$ \\
\hline & $07-20-94$ & $<5.0$ & $<5.0$ & $<5.0$ & $<5.0$ & $<5.0$ & $<5.0$ & $<5.0$ & $<5.0$ & $<5.0$ \\
\hline $26 \mathrm{dcb} 2$ & $10-07-94$ & $<5.0$ & $<5.0$ & $<5.0$ & $<5.0$ & $<5.0$ & $<5.0$ & $<5.0$ & $<5.0$ & $<5.0$ \\
\hline
\end{tabular}

